DAIANE MAYARA ALVES

A experiência da Educação Permanente em Saúde no município de Registro, São Paulo

São Paulo

2019 

DAIANE MAYARA ALVES

\section{A experiência da Educação Permanente em Saúde no município de Registro, São Paulo}

\section{Versão Original}

Dissertação apresentada à Faculdade de Odontologia da Universidade de São Paulo, Programa Mestrado Profissional Interunidades em Formação Interdisciplinar em Saúde, para obter o título de Mestre em Ciências da Saúde.

Orientadora: Prof. ${ }^{a}$ Dr. ${ }^{a}$ Simone Rennó Junqueira 
Autorizo a reprodução e divulgação total ou parcial deste trabalho, por qualquer meio convencional ou eletrônico, para fins de estudo e pesquisa, desde que citada a fonte.

Catalogação-na-Publicação

Serviço de Documentação Odontológica

Faculdade de Odontologia da Universidade de São Paulo

Alves, Daiane Mayara.

A experiência da Educação Permanente em Saúde no município de Registro, São Paulo / Daiane Mayara Alves ; orientador Simone Rennó Junqueira -- São Paulo, 2019.

104 p. : fig.; $30 \mathrm{~cm}$.

Dissertação (Mestrado Profissional) - Programa de Pós-Graduação Interunidades em Formação Interdisciplinar em Ciências da Saúde. Faculdade de Odontologia da Universidade de São Paulo.

Versão original

1. Educação em Saúde. 2. Sistema Único de Saúde. 3. Avaliação em Saúde. 4. Pesquisa qualitativa. I. Junqueira, Simone Rennó. II. Título. 
Alves DM. A experiência da Educação Permanente em Saúde no município de Registro, São Paulo. Dissertação apresentada à Faculdade de Odontologia da Universidade de São Paulo para obtenção do título de Mestre em Ciências da Saúde.

Aprovado em: / /2019

\section{Banca Examinadora}

$\operatorname{Prof}(\mathrm{a}) . \operatorname{Dr}(\mathrm{a})$.

Instituição: Julgamento:

$\operatorname{Prof}(\mathrm{a}) . \operatorname{Dr}(\mathrm{a})$.

Instituição: Julgamento:

Prof(a). Dr(a).

Instituição: Julgamento: 

À Deus e Nossa Senhora que jamais me abandonaram nos momentos difíceis, a minha mãe, a qual quero ser sempre motivo de orgulho e que não mediu esforços para que mais este sonho se tornasse realidade.

DAIANE MAYARA ALVES 



\section{AGRADECIMENTOS}

A Deus por me dar sabedoria e discernimento e ter me sustentado até aqui.

Aos meus pais, por todo esforço em tornar mais este sonho em realidade, em especial minha mãe por acreditar em cada objetivo meu.

A toda equipe, professores e colegas do programa Mestrado Profissional Interunidades em Formação Interdisciplinar em Saúde, da Faculdade de Odontologia da universidade de São Paulo, a qual me acolheu tão bem e pude ter a oportunidade de aprender com as experiências de cada um.

A minha orientadora, professora Doutora Simone Rennó Junqueira, por todo apoio e paciência e pelo empenho e compromisso em me orientar na realização deste trabalho.

A todos os colaboradores participantes da pesquisa do município de Registro-SP.

A todos que passaram por minha vida nestes últimos três anos, que de alguma forma, inspiraram-me a não desistir deste sonho. 

"Ele não sabia que era impossível. Foi lá e fez". Jean Cocteau 



\section{RESUMO}

Alves DM. A experiência da Educação Permanente em Saúde no município de Registro, São Paulo. [dissertação] São Paulo: Universidade de São Paulo, Faculdade de Odontologia; 2019. Versão Original.

Com a criação do Sistema Único de Saúde, as mudanças sociais e os novos perfis epidemiológicos, foi necessário ocorrer uma reformulação no processo de trabalho dos profissionais da área, uma vez que os serviços públicos de saúde deveriam possibilitar o acesso universal e desenvolver uma atenção integral ao usuário e, não mais, uma atuação centrada na doença, no especialismo, e na atuação uniprofissional. Nesse pressuposto, os profissionais da saúde necessitam de constante atualização e a Educação Permanente em Saúde (EPS) é considerada uma importante ferramenta que pode auxiliar na transformação das práticas profissionais, pois viabiliza a construção de conhecimentos por meio da aprendizagem significativa, buscando uma formação integral e contínua, a partir de temas que surgem das necessidades identificadas no próprio ambiente de trabalho. O objetivo do estudo foi conhecer o processo de planejamento e organização da EPS no município de Registro- SP, detectar as potencialidades e limitações trazidas pelos participantes do estudo e trazer novas propostas de acordo com a regulamentação vigente da EPS, resultando em seu produto educacional. Para isso, foi realizado um estudo de campo de base qualitativa, segundo proposta de Deslandes (1997) para a avaliação de programas e serviços. Para essa avaliação efetuou-se um levantamento sobre o material relacionado à EPS no município, complementado por entrevistas individuais, conduzidas por um questionário estruturado e desenvolvido com base na cartilha do Ministério da Saúde sobre a Política Nacional de Educação Permanente em Saúde (PNEPS), com o responsável pela EPS, seis profissionais, entre médicos, enfermeiros e dentistas, atuantes na Estratégia Saúde da Família em cada um dos três distritos municipal e também com dois profissionais do Núcleo de Apoio à Saúde da Família, independentemente da categoria. Coordenadores dos três distritos de saúde foram convidados a participar de um Grupo Focal para exporem suas percepções. Os resultados evidenciaram que, à exceção dos coordenadores de distrito e do responsável pela EPS, demais entrevistados não conheciam a PNEPS e careciam de 
mais discussões conceituais sobre o tema. No olhar dos colaboradores da EPS, os profissionais das unidades de saúde participavam do processo de elaboração da EPS, e eram consideradas a realidade, necessidade e as expectativas locais e da equipe para sua formulação. Contudo, esses profissionais não se reconheciam participantes desse processo, ainda que considerassem ser importante essa participação junto aos organizadores. Percebeu-se certa confusão entre os termos Educação Permanente e Educação Continuada pelos participantes, o que pode ter dificultado o reconhecimento dessa participação. A EPS no município ainda se apresenta em processo de implantação, observou-se que muito se alcançou, porém, muito ainda há que ser feito com o objetivo de aproveitar melhor essa ferramenta, como por exemplo, a elaboração de um plano municipal de EPS e de mecanismos de avaliação e monitoramento das ações já realizadas. Apontaram como sugestões a criação de um núcleo de EPS, o que poderia aumentar a rede de profissionais envolvidos com o desenvolvimento das ações. Assim, percebeu-se o interesse e possibilidade de que o processo de implantação da EPS no município continue e seja valorizado.

Palavras-chave: Educação em saúde. Sistema Único de Saúde. Avaliação em saúde. Pesquisa qualitativa. 


\begin{abstract}
Alves DM. The experience of Permanent Health Education in Registro, São Paulo. [dissertation]. Sao Paulo: Universidade de São Paulo, Faculdade de Odontologia; 2019. Versão Original.
\end{abstract}

With the creation of the Unified Health System, social changes and new epidemiological profiles, it was necessary to reformulate the work process of professionals of area, since public health services should enable universal access and develop comprehensive care. to the user and no longer an action centered on disease, specialism, and uniprofessional performance. In this assumption, health professionals need constant updating and Permanent Health Education (PHE) is considered an important tool that can help in the transformation of professional practices, as it enables the construction of knowledge through meaningful learning, seeking a comprehensive education and training. based on themes that arise from the needs identified in the work environment itself. The objective of the study was to learn about the planning and organization process of EPS in the municipality of Registro-SP, detect the potentialities and limitations brought by the study participants and bring new proposals in accordance with the current regulations of EPS resulting in its educational product. For this, a qualitative field study was carried out, according to the proposal of Deslandes (1997) for the evaluation of programs and services. For this evaluation, a survey was conducted on EPS-related material in the municipality, complemented by individual interviews, conducted by a structured questionnaire developed on the basis of the Ministry of Health's booklet on the National Policy on Permanent Education in Health (PNEPS). the head of the EPS, with six professionals, including doctors, nurses and dentists, working in the Family Health Strategy in each of the three municipal districts and also with two professionals from the Family Health Support Center, regardless of category. Coordinators from the three health districts were invited to participate in a Focus Group to share their perceptions. The results showed that, except for the district coordinators and the responsible for the EPS, other interviewees did not know about PNEPS and needed more conceptual discussions about the subject. In the eyes of the employees of the EPS, the health unit professionals participated in the process of elaborating the EPS, and were considered the reality, need and local and team 
expectations for its formulation. However, these professionals did not recognize themselves as participants in this process, even though they considered this participation with the organizers to be important. There was some confusion between the terms Permanent Education and Continuing Education by the participants, which may have made it difficult to recognize this participation. The EPS in the municipality is still in the process of implementation, it was observed that much has been achieved, but much remains to be done in order to make better use of this tool, such as the elaboration of a municipal EPS plan, and mechanisms for evaluation and monitoring of actions already taken. They pointed as suggestions the creation of a nucleus of EPS, which could increase the network of professionals involved with the development of the actions. Thus, it was perceived the interest and possibility that the process of implementation of EPS in the municipality continues and be valued.

Keywords: Health Education. Unified Health System. Health assessment. Qualitative research. 


\section{LISTA DE ILUSTRAÇÕES}

Figura 4.1 - Mapa do Estado de São Paulo, segundo os Departamentos Regionais de Saúde, 2012.

Figura 4.2 - Mapa do município de Registro-SP com a localização dos Distritos de Saúde, 2018

Figura 5.1 - Organograma com os colaboradores no planejamento da Educação Permanente em Saúde, de nível de Secretaria Municipal de Saúde, de Registro, 2018. 48

Figura 5.2- Profissionais de nível superior atuantes na Estratégia Saúde da Família, segundo formação pós graduação, 2018 .56

Figura 5.3 - Distribuição das instituições públicas de ensino superior dos cursos de especialização realizados pelos profissionais da saúde de nível superior atuantes na Estratégia Saúde da Família, 2018. 57

Quadro 5.1- Percepções dos apoiadores e profissionais da Estratégia Saúde da Família sobre a Educação Permanente em Saúde. Registro, 2018.....63 



\section{LISTA DE ABREVIATURAS E SIGLAS}

ACS

Agente Comunitário de Saúde

ASB

Auxiliar de Saúde Bucal

CAPS

Centro de Atenção Psicossocial

CEFORH Centro de Formação de Recursos Humanos

CEM

Centro de Especialidade Médica

CEO

Centro de Especialidade Odontológica

CEREST Centro de Referência em Saúde do Trabalhador

CIES

Comissões Permanentes de Integração Ensino-Serviço

CONSAÚDE Consórcio Intermunicipal de Saúde do Vale do Ribeira

DRS

Departamento Regional de Saúde

$\mathrm{EaD}$

Educação a Distância

EPS

Educação Permanente em Saúde

ESF

Estratégia Saúde da Família

ETSUS

Escolas Técnicas do Sistema Único de Saúde

FIOCRUZ

Fundação Oswaldo Cruz

IBGE

Instituto Brasileiro de Geografia e Estatística

IDH-M

Índice de Desenvolvimento Humano Municipal

MS

Ministério da Saúde

NASF

Núcleo de Apoio à Saúde da Família

$\mathrm{NEPH}$

Núcleo de Educação Permanente em Saúde e Humanização

NOB/RH- SUS Norma Operacional Básica de Recursos Humanos para o Sistema Único de Saúde

PACS Programa de Agentes Comunitários de Saúde

PAS Programação Anual de Saúde

PEEPS Plano Estadual de Educação Permanente em Saúde do estado de São Paulo

PEPS Politica de Educação Permanente do Sistema Único de Saúde

PMAQ Programa de Melhoria do Acesso e da Qualidade

PMAQ-AB Programa de Melhoria do Acesso e da Qualidade da Atenção Básica

PMM Programa Mais Médicos

PMS Plano Municipal de Saúde 


$\begin{array}{ll}\text { PNAB } & \text { Política Nacional de Atenção Básica } \\ \text { PNEPS } & \text { Política Nacional de Educação Permanente em Saúde } \\ \text { PPA } & \text { Plano Plurianual } \\ \text { Pro EPS-SUS } & \text { Programa para o Fortalecimento das Práticas de Educação } \\ & \text { Permanente em Saúde no Sistema Único de Saúde } \\ \text { RAPS } & \text { Rede de Atenção Psicossocial } \\ \text { RUE } & \text { Rede de Urgência e Emergência } \\ \text { SES } & \text { Secretarias Estaduais de Saúde } \\ \text { SES-SP } & \text { Secretaria de Estado da Saúde de São Paulo } \\ \text { SMS } & \text { Secretaria Municipal de Saúde } \\ \text { SUS } & \text { Sistema Único de Saúde } \\ \text { TCLE } & \text { Termo de Consentimento Livre e Esclarecido } \\ \text { UAB } & \text { Universidade Aberta do Brasil } \\ \text { UBS } & \text { Unidade Básica de Saúde } \\ \text { UBDS } & \text { Unidade Básica e Distrital de Saúde } \\ \text { UNA-SUS } & \text { Universidade Aberta do Sistema Único de Saúde } \\ \text { UNIFESP } & \text { Universidade Federal de São Paulo } \\ \text { UPA } & \text { Unidade de Pronto Atendimento } \\ \text { USF } & \text { Unidade Saúde da Família }\end{array}$




\section{SUMÁRIO}

1 INTRODUÇÃO

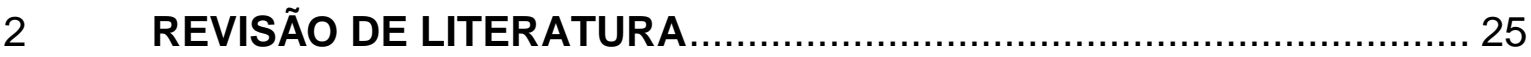

2.1 MARCOS REFERENCIAIS RELATIVOS ÀS PROPOSTAS DE EDUCAÇÃO PERMANENTE EM SAÚDE …………............................ 25

2.2 EDUCAÇÃO PERMANENTE EM SAÚDE: ASPECTOS CONCEITUAIS

2.3 PROCESSOS DE ENSINO- APRENDIZAGEM PROPOSTOS

PARA A EDUCAÇÃO PERMANENTE EM SAÚDE.

2.4 A EDUCAÇÃO A DISTÂNCIA COMO FERRAMENTA FACILITADORA

DA EDUCAÇÃO PERMANENTE EM SAÚDE ........................................ 33

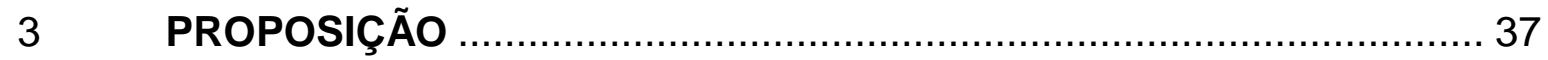

4 METODOLOGIA

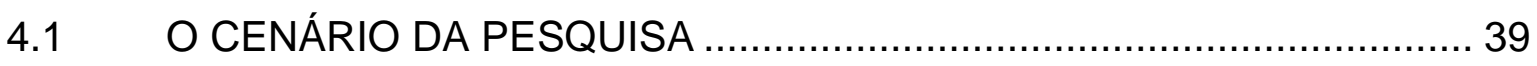

4.2 DESENVOLVIMENTO METODOLÓGICO …...................................... 42

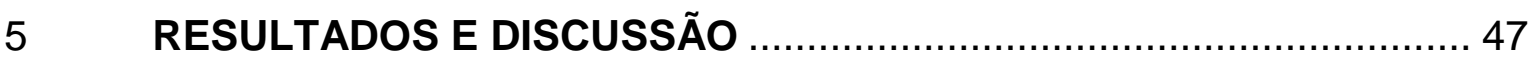

5.1 A EXPERIÊNCIA DA EDUCAÇÃO PERMANENTE EM SAÚDE

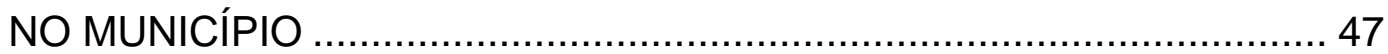

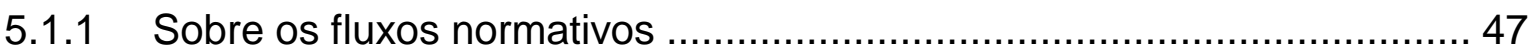

5.1.2 Sobre a qualificação dos trabalhadores da Estratégia Saúde da Família. 54

5.2 REPRESENTAÇÕES DA EDUCAÇÃO PERMANENTE EM SAÚDE

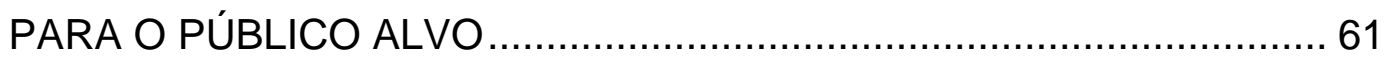

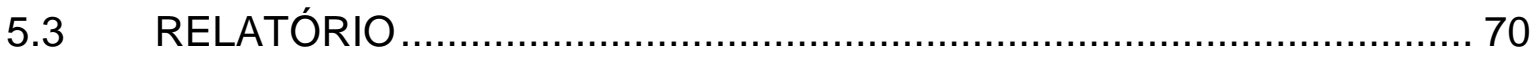

6 CONCLUSÃO

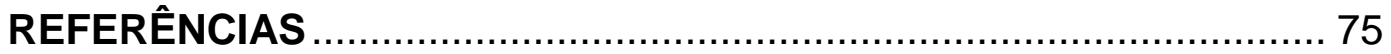

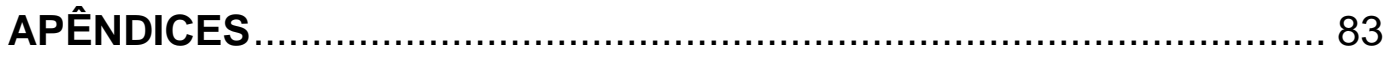

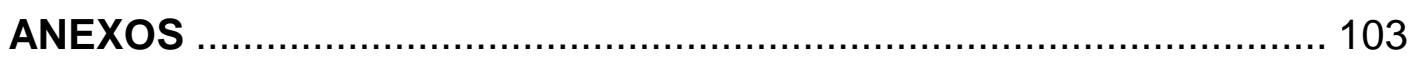







\section{INTRODUÇÃO}

Após a criação do Sistema Único de Saúde (SUS), que propõe romper com antigos conceitos de saúde e doença voltados para cura, vivencia-se hoje um período em que há necessidade de mudanças no aparelho formador dos profissionais da saúde, uma vez que o SUS tem assumido um papel ativo na reorientação das estratégias e modos de assistência à saúde individual e coletiva, sendo necessária a superação do biologicismo, do modelo clínico hegemônico, centrado no saber, na doença, e no especialismo, assegurando ao usuário uma cobertura universal e integral da promoção, da proteção e da recuperação da saúde ${ }^{1}$.

Pensar em ações para promover a saúde é muito mais do que tratar a doença. Assim, como consta na Constituição Federal de 1988, reforçada pela Lei n 8.080/90 de 1990 (Lei Orgânica da Saúde), as ações de saúde têm por objetivo a promoção e proteção da saúde, a redução do risco de doença e de outros agravos e a recuperação da saúde, tendo como diretriz o atendimento integral, com prioridade para as atividades preventivas, sem prejuízo dos serviços assistenciais ${ }^{2,3}$.

Dessa maneira, para que se consolide essa mudança nas práticas de saúde preconizadas pelo SUS, foram ocorrendo, ao longo dos anos, reformulações no processo de trabalho assistencial, sendo necessária uma constante capacitação dos recursos humanos atuantes nos serviços públicos de saúde ${ }^{4}$.

Assim, a formação do profissional de saúde deve contemplar o sistema de saúde vigente no país, sendo necessário o conhecimento científico e tecnológico atrelado ao conhecimento de natureza humanística e social, interdisciplinar e integral, relativo ao processo de cuidar ${ }^{1}$.

Concomitantemente, o conhecimento e a informação estão em constantes mudanças, exigindo atualização dos profissionais, e a graduação, em qualquer área de saúde, frequentemente não é suficiente para garantir a qualificação necessária, devendo se estender para outros espaços, como os serviços do SUS'1. A maioria dos cursos ofertados na área de saúde, seja de nível técnico ou superior, forma profissionais, muitas das vezes, distantes das necessidades e realidades de saúde da população, bem como das diretrizes do SUS 5 . 
Por consequência, normas, portarias, diretrizes e outros instrumentos legais foram criados com o objetivo de organizar uma política de recursos humanos que articulasse saberes, práticas e valores condizentes com os princípios e diretrizes vigentes do SUS 4 .

Dentre as propostas, pensou-se em estratégias que contribuíssem para transformar a organização do processo de formação dos futuros profissionais atuantes na saúde, bem como no processo de trabalho administrativo e assistencial dos profissionais da rede pública, buscando aproximar as instituições formadoras e o SUS, ainda trazer propostas de formação de acordo com a realidade e necessidade de cada região ${ }^{6}$.

É nesse contexto que o Ministério da Saúde (MS) tem elaborado, ao longo dos anos, estratégias e políticas voltadas para a oportuna formação e qualificação dos trabalhadores de saúde, de acordo com as necessidades de saúde da população e do território, com o intuito de desenvolvimento e fortalecimento do SUS. Dentre as estratégias, insere-se a criação e implantação da Política Nacional de Educação Permanente em Saúde (PNEPS) ${ }^{7}$.

A Educação Permanente em Saúde (EPS) é considerada o aprendizado no trabalho, facilitando a participação dos profissionais, onde o aprender e o ensinar se articulam, se integram ao cotidiano do trabalho. Tem o objetivo de constituir relações sólidas, institucionais e pessoais entre os trabalhadores, gestores, usuários, professores e acadêmicos, que possibilitem a transformação das práticas profissionais e do ambiente de trabalho, a partir da articulação das necessidades dos serviços de saúde e dos profissionais atuantes ${ }^{8}$.

O ponto chave para um bom resultado da EPS é seu planejamento e realização a partir dos problemas enfrentados pelos trabalhadores e usuários nas práticas do serviço, de acordo com a realidade e as necessidades da região e do cotidiano dos profissionais, considerando ainda os conhecimentos, os relatos, as experiências e as crenças que a equipe já possui ${ }^{9}$.

Entretanto, sem desconsiderar o desafio de implementar uma política apropriada de recursos humanos na saúde, alguns municípios ainda apresentam dificuldades em efetuar essa responsabilidade sanitária. Entre elas, podem ser elencadas a não realização oportuna de um planejamento estratégico dessas ações, resultando em desmobilização dos potenciais participantes para determinadas ações; baixa oferta para qualificações de todos os trabalhadores das equipes de saúde; não 
multiplicação ou repasse dos aprendizados adquiridos para suas equipes de trabalho e a persistência por parte dos mediadores e/ ou facilitadores da EPS, nos modelos tradicionais de aula, não considerando novas metodologias de ensino-aprendizagem para tais processos ${ }^{4}$.

Embora o desenvolvimento da PNEPS responda a um enorme desafio posto à gestão dos estados e municípios, alguns mostraram que, com planejamento e organização, é possível enfrentar tal desafio. Exemplo disso é o Estado de Santa Catarina, que criou uma teia de cooperação e compartilhamento de saberes, possibilidades e potencialidades, identificando parceiros nas dezesseis regiões de saúde do estado, como também, realizando pactuações entre atores institucionais. Toda essa experiência foi retratada em dois livros, que relatam o esforço de um coletivo que vem se dedicando a aplicar os princípios da EPS na transformação das práticas em saúde no estado, desde 2004, quando a Política foi criada ${ }^{10,11}$.

Outras experiências e desafios também são retratados no documento "Análise da Política de Educação Permanente do SUS (PEPS), implementada pelas Secretarias Estaduais de Saúde (SES)", considerando as 27 Unidades Federativas, sendo 26 Estados e um Distrito Federal ${ }^{12}$. Esse documento traz que a EPS tem sido compreendida como uma estratégia transformadora das práticas de saúde, com grande potencial para o rompimento do paradigma tradicional que orienta os processos de formação dos trabalhadores da saúde, pois está centrada em processos de ensino-aprendizagem, no qual o próprio sujeito que aprende, educa, sendo considerado um agente ativo, autônomo e gestor de sua educação ${ }^{12}$.

Frente a esses aspectos, este estudo pretendeu explorar o processo de planejamento e organização da EPS em um município de médio porte do interior paulista, seguindo a proposta de Deslandes ${ }^{13}$ para a avaliação de programas e serviços, uma vez que a EPS é uma ferramenta importante para a formação e o desenvolvimento de recursos humanos para a saúde, compatíveis com os princípios do SUS. 



\section{REVISÃO DA LITERATURA}

\subsection{MARCOS REFERENCIAIS RELATIVOS ÀS PROPOSTAS DE EDUCAÇÃO PERMANENTE EM SAÚDE}

É de grande valia resgatar parte do percurso histórico, até então percorrido, para que se desenvolvesse uma política adequada de EPS. A Constituição Federal de 1988 já previa, em seu artigo 200, entre outras atribuições, o papel do Sistema Único de Saúde em "ordenar a formação de recursos humanos na área de saúde"2.

Além dessa previsão constitucional, a Lei n 8.080, de 19 de setembro de 1990, conhecida como Lei Orgânica da Saúde, na qual dispõe sobre a organização e o funcionamento dos serviços de saúde, reforça, em seu Art. $6^{\circ}$, o compromisso do SUS com a formação de recursos humanos e, para isso, em seu Art. $14^{\circ}$ trata da criação e funções das comissões permanentes de integração entre os serviços de saúde e as instituições de ensino profissional e superior ${ }^{3}$.

Foi a partir da criação do Departamento de Gestão da Educação na Saúde em 2003, que o Ministério da Saúde assumiu seu papel de gestor federal do Sistema Único de Saúde, no que se refere à ordenação da formação e à Educação Permanente dos profissionais atuantes no SUS, tendo como a principal marca de gestão, resultante da criação desse departamento a relação entre educação e trabalho em saúde . $^{6}$

No Brasil, a regulamentação da Educação Permanente tem como marco inicial a elaboração e publicação da Portaria n 198/GM, de 13 de fevereiro de 2004, que instituiu a Política Nacional de Educação Permanente em Saúde (PNEPS) e cria os Polos de Educação Permanente em Saúde, com o objetivo de identificar as necessidades de formação dos trabalhadores de cada região, traçar estratégias para transformar e qualificar a atenção à saúde e, por conseguinte, buscar o fortalecimento do SUS 8 .

Em 2005, o documento "Princípios e Diretrizes para a Gestão do Trabalho no SUS NOB/RH-SUS", exalta a importância da formação de Recursos Humanos no setor da saúde e traz que as ações de Educação Permanente devem ser planejadas baseando-se nas atribuições e competências institucionais de cada esfera de gestão, 
bem como na realidade e atribuições definidas para os diferentes trabalhadores do SUS ${ }^{14}$.

Em 22 de fevereiro de 2006, foi publicada a Portaria no399/GM, que divulgou o Pacto pela Saúde, formado por três eixos: o Pacto pela Vida, o Pacto em Defesa do SUS e o Pacto de Gestão do SUS. O Pacto de Gestão do SUS contempla a educação na saúde como uma de suas diretrizes e deixa clara a importância da EPS e, mais uma vez, a responsabilidade e obrigatoriedade da União, dos estados e dos municípios para a realização de ações de EPS, pautadas na integralidade, nas necessidades de saúde daquela região e nas diretrizes do SUS ${ }^{15}$.

Dentre suas diretrizes é proposto que se avance na implementação da Política Nacional de Educação Permanente por meio da compreensão dos conceitos de formação e Educação Permanente, considerando a EPS parte essencial e estratégica de uma política de formação e desenvolvimento dos trabalhadores do SUS. Reforça ainda que a EPS deve comportar a adoção de diferentes metodologias e técnicas de ensino-aprendizagem e ser aplicada de forma descentralizada ${ }^{15}$.

Nesse mesmo período seguiu-se a Portaria no 648/GM, de 28 de março de 2006, que aprovou a Política Nacional de Atenção Básica (PNAB), estabelecendo a revisão de diretrizes e normas para a organização da Atenção Básica, para a Estratégia Saúde da Família (ESF) e o Programa de Agentes Comunitários de Saúde (PACS) $^{16}$.

Revogada em 21 de outubro de 2011 pela Portaria ํㅡㄴ 2.488 , a proposta da PNAB manteve a responsabilidade das três esferas de governo em desenvolver meios técnicos e estratégicos de qualificar os trabalhadores para o SUS, seja na gestão ou na atenção à saúde, viabilizando a formação e Educação Permanente desses profissionais por meio da articulação entre instituições para formação ${ }^{17}$.

Passados três anos desde a publicação da primeira portaria de Educação Permanente em Saúde, observando que havia pontos importantes, os quais ainda não estavam listados, em 20 de agosto de 2007, entrou em vigência a Portaria GM/MS n 1.996, que dispõe sobre as diretrizes para a implementação da PNEPS e traz novas diretrizes para a implementação da PNEPS, de acordo com as diretrizes operacionais e ao regulamento do Pacto pela Saúde ${ }^{18}$. 
Ambas as portarias normativas da EPS, propõem que os processos de qualificação dos profissionais tomem como referência as necessidades e a realidade local de saúde, que tenham como propósito a transformação das práticas profissionais e da própria organização do trabalho sendo estruturada a partir da problematização dos processos de trabalho de saúde ${ }^{19}$.

A principal diferença entre as duas portarias está nas diretrizes, com a alteração da política no sentido de adequação ao Pacto pela Saúde, com maior protagonismo do colegiado de gestão regional, a descentralização dos recursos financeiros e nos dispositivos para a sua implementação nos estados ${ }^{19}$.

A Portaria GM/MS $n^{\circ} 1.996$ reforça alguns aspectos relevantes, como considerar as especificidades e a superação das desigualdades regionais para o desenvolvimento do trabalho em saúde, portanto, o objetivo da EPS é o de ser planejada dentro do território e com os profissionais que estarão envolvidos, buscando assim, ofertar uma formação dentro da realidade e necessidade local ${ }^{18}$.

Essa portaria trouxe, ainda, que a condução regional da Política Nacional de Educação Permanente em Saúde se dará por meio dos Colegiados de Gestão Regional, com a participação das Comissões Permanentes de Integração EnsinoServiço (CIES). Cabe a esse colegiado elaborar o planejamento considerando as especificidades locais e a Política de Educação Permanente em Saúde nas três esferas de gestão (federal, estadual e municipal), elaborar um Plano de Ação Regional que defina as prioridades, as responsabilidades de cada ente, o apoio e recursos para o desenvolvimento das ações, bem como, instituir processo de acompanhamento, monitoramento, avaliações das ações e estratégias de Educação em Saúde implementadas na região ${ }^{18}$.

Essa portaria aborda ainda sobre a transferência dos recursos financeiros que se dará aos fundos estaduais e do distrito federal, ou de um ou mais munícipios, conforme pactuações estabelecidas no regulamento do Pacto pela Saúde, sendo os mesmos repassados apenas aos municípios que tiverem assinado seus termos de compromisso de gestão ${ }^{18}$.

A distribuição dos recursos para a PNEPS levará em conta fatores como o Índice de Desenvolvimento Humano Municipal (IDH-M), uma vez que, quanto menor, maiores as barreiras sociais e menor a disponibilidade de instituições de ensino com cursos de saúde, que poderiam contribuir com a diminuição das inequidades ${ }^{18}$. 
Em 21 de setembro de 2017, entrou em vigor a Portaria $n^{\circ}$ 2.436, reapresentando a PNAB, com a revisão de diretrizes para a organização da Atenção Básica, no âmbito do SUS, mas mantendo o destaque para a importância da formação e da EPS, como parte do processo de trabalho das equipes que atuam na Atenção Básica ${ }^{20}$.

Em 28 de setembro do mesmo ano, surgem duas novas portarias de consolidação; a n 2/GM/MS, em seu art. 8º, inciso II, dispõe sobre a Política Nacional de Educação Permanente em Saúde, considerando-a política de organização do $S^{21}$, e a n 6/GM/MS, que traz a consolidação das normas sobre o financiamento e a transferência dos recursos federais para as ações e os serviços de saúde do SUS, na forma de blocos de financiamento, da qual a Educação em Saúde também faz parte $^{22}$.

Em 28 de novembro de 2017, foi publicada a Portaria nํ 3.194, a qual dispõe sobre o Programa para o Fortalecimento das Práticas de Educação Permanente em Saúde no Sistema Único de Saúde (PRO EPS-SUS). Referida portaria reforça a necessidade de se desenvolverem ações para a formação e Educação Permanente, explicitando o objetivo geral do PRO EPS-SUS em estimular, acompanhar e fortalecer a qualificação profissional dos trabalhadores da área da saúde para a transformação das práticas de saúde em direção ao atendimento dos princípios fundamentais do SUS, a partir da realidade local e da análise coletiva dos processos de trabalho ${ }^{23}$.

O PRO EPS-SUS tem por objetivo fortalecer as ações de EPS nos territórios, dar centralidade aos processos de gestão da PNEPS na lógica do modelo de atenção à saúde e reconhecer as contribuições dos principais atores nesse processo, além de tratar da execução dos recursos repassados com base nos incentivos financeiros para a elaboração de Plano Estadual de Educação Permanente em Saúde ${ }^{23}$.

Relacionada a essa norma, em 7 de dezembro de 2017, foi divulgada por meio da Portaria no 3.342, a lista de Distrito Federal e municípios habilitados ao recebimento do incentivo financeiro de custeio para a execução de ações de Educação Permanente em Saúde pelas Equipes de Atenção Básica, de que trata a Seção II da Portaria no 3.194/2017/GM/MS ${ }^{23,24}$. Nesse documento, o município desse estudo entrou como um dos contemplados ao recebimento do incentivo ${ }^{24}$. 


\subsection{EDUCAÇÃO PERMANENTE EM SAÚDE: ASPECTOS CONCEITUAIS}

Ao se considerar o processo de educação em serviço na área da saúde, é possível identificar o uso de conceitos aparentemente semelhantes e, por isso, muitas vezes utilizados de maneira equivocada entre os profissionais de saúde. Entretanto, tais conceitos não são equivalentes e ainda geram certa dificuldade na sua compreensão e aplicabilidade, especialmente os termos "Educação Continuada" e "Educação Permanente em Saúde"25.

É comum ocorrer uma confusão entre os trabalhadores, sobre os processos educativos que podem acontecer na área da saúde. Como ação educativa, a Educação Permanente deve ser diferenciada de outros processos educacionais ${ }^{26}$, uma vez que, a própria falta do entendimento sobre o processo educativo pelos trabalhadores pode ser considerada um fator de interferência para a não institucionalidade da PNEPS ${ }^{27}$.

Em síntese, a Educação Permanente e a Educação Continuada são duas propostas distintas, utilizadas em diferentes momentos de acordo com as necessidades de qualificação ${ }^{26}$.

A Educação Continuada representa uma continuidade do modelo escolar ou acadêmico por meio de escolarização formal e da transmissão de conhecimento de maneira sequencial e acumulativa. Geralmente está focada no âmbito individual e direcionada para categorias profissionais, tem caráter pontual, descendente e fragmentada ${ }^{26}$. Ela pressupõe a reprodução de conhecimentos com ênfase em cursos e treinamentos padronizados, buscando a atualização de técnicas com temas elaborados previamente ${ }^{26}$.

Relativo à Educação Permanente em Saúde, a Portaria GM/MS № 1.996, de 20 de agosto de 2007, traz em seu texto o que é a aprendizagem no trabalho, no qual o aprender e o ensinar se incorporam ao cotidiano das pessoas e do trabalho ${ }^{18}$.

A EPS é feita a partir dos problemas enfrentados pelos trabalhadores, na realidade local, leva em consideração os conhecimentos e as experiências que as pessoas já trazem na sua vivência profissional e se baseia na aprendizagem significativa, na reflexão crítica, na possibilidade de transformar as práticas profissionais e da própria organização do trabalho ${ }^{18}$. 
Assim, o enfoque da Educação Permanente é o de incorporar o ensino e o aprendizado dos trabalhadores dentro das próprias instituições. Ela trabalha com ferramentas que buscam a transformação das práticas de atenção, objetivando uma formação integral e contínua a partir de temas que surgem da necessidade de se construir propostas de melhorias e soluções dos problemas existentes, identificado no exercício do trabalho, na gestão e no controle social, por meio do compartilhamento dos significados e sentidos dos objetos ${ }^{26}$.

Ainda podemos destacar como características essenciais das ações de Educação Permanente em Saúde, a lógica ascendente, descentralizada e transdisciplinar de ensino, estimulo da reflexão coletiva sobre o processo de trabalho, o trabalho em equipe multiprofissional e transdisciplinar, e o incentivo a problematização, e o "desconstrutivismo"6,28.

Nessa proposta, as práticas são definidas por múltiplos fatores, e buscam trabalhar com elementos que produzam sentido para os envolvidos, uma vez que cada trabalhador e usuário têm ideias, valores e concepções sobre saúde e trabalho em saúde e como deve ser feito ${ }^{28}$.

A EPS busca a transformação das praticas a partir da análise coletiva dos processos de trabalho, identificando os nós críticos a serem enfrentados na atenção ou na gestão, e permite a construção de estratégias contextualizadas que promovam o diálogo entre políticas gerais e a singularidade de lugares e pessoas ${ }^{28}$.

Ela constitui-se um processo de permanente aquisição de informações pelo trabalhador, que compreende a formação profissional, qualificação, requalificação, especialização, aperfeiçoamento e a atualização de todo e qualquer conhecimento, por meio de escolarização formal ou não formal, de vivências, de experiências, no âmbito institucional ou fora dele ${ }^{14}$, sendo uma importante estratégia às transformações do trabalho para que esse venha a ser lugar de atuação crítica, reflexiva, compromissada e tecnicamente competente, o que possibilitaria construir no SUS uma rede-escola 29 .

Para atingir esses propósitos, os responsáveis pela elaboração da EPS devem realizar um plano norteador dos processos educativos dos trabalhadores, contendo a caracterização da região, levando em consideração sua realidade epidemiológica, disponibilidade de estrutura física e de recursos humanos, identificação dos problemas de saúde e de gestão enfrentados pelas equipes, detectar as necessidades de formação em saúde, conhecer o perfil dos profissionais, definir o planejamento, 
priorizar as metas de ações, planejar os recursos e meios necessários para a realização das atividades e considerar as avaliações dos resultados alcançados ${ }^{18}$.

Nesse pressuposto, busca-se usar a EPS para melhorar a formação dos trabalhadores do serviço público e, consequentemente, fortalecer o SUS, uma vez que a EPS possibilita, concomitantemente, preencher lacunas de conhecimentos identificadas no cotidiano do trabalho, transformar as práticas pessoais e a própria organização dos processos de trabalho ${ }^{5}$.

\subsection{PROCESSOS DE ENSINO-APRENDIZAGEM PROPOSTOS PARA A EDUCAÇÃO PERMANENTE EM SAÚDE}

Frente às transformações que ocorreram ao longo dos anos no SUS, solicitando mudanças na formação dos profissionais da saúde, necessárias para o trabalho de acordo com as novas organizações e conceitos de saúde, foi preciso pensar em metodologias que fossem capazes de provocar importantes repercussões nas estratégias e modos de ensinar e aprender 6 .

Conforme o educador e filósofo, Paulo Freire, ensinar não é apenas transferir conhecimento, bem como aprender não é memorizar o conteúdo transferido, mas sim, criar possibilidades para a sua produção ${ }^{30}$.

Dessa forma, a formação permanente dos profissionais exige-se uma reflexão crítica sobre a prática, na qual ensinar pressupõe respeito aos saberes do educando, sua autonomia, dignidade e identidade, ou seja, aprender é muito mais que repetir a lição dada, é construir e reconstruir para mudar ${ }^{30}$.

Pautada nessa concepção pedagógica, transformadora e emancipatória, a Educação Permanente é uma política capaz de orientar a formação e qualificação dos trabalhadores que se baseia na aprendizagem significativa (que promove e produz sentidos) e na problematização. Propondo, assim, que a transformação das práticas profissionais e, da própria organização do trabalho, deva estar fundamentada nas necessidades, expectativas, singularidade de cada região e que ainda os processos de qualificação ocorram de forma descentralizada, ascendente e transdisciplinar, valorizando o local de trabalho como fonte de conhecimento ${ }^{5,6}$. 
No contexto da saúde, existem diferentes opções pedagógicas a serem empregadas nos processos de formações, dentre elas, pode-se enfatizar a pedagogia da transmissão e da problematizadora, e as estratégias de ensino utilizadas devem ter coerência com o modelo pedagógico adotado ${ }^{31}$.

Vale aqui mencionar, que existe uma vasta possibilidade de ações de educação, como por exemplo, cursos presenciais e a distância, aprendizagem em serviço, grupos formais de estudos, intercâmbios ou estágios, oficinas, seminários, congressos e outras, que contribuem para a formação, atualização, qualificação profissional, melhorias nos processos de trabalho, e desenvolvimento dos trabalhadores, em consonância com as diretrizes institucionais do SUS ${ }^{32}$.

A pedagogia da transmissão, também conhecida como "Educação Bancária", é baseada na transmissão do conhecimento e da experiência do professor, e conduz os educandos a memorização mecânica do conteúdo narrado, sendo o aluno um tomador de notas. Essa pedagogia tem suas limitações, uma vez que traz conteúdos impostos e não se baseia em experiências e vivências, mas sim; em conhecimentos sistematizados e generalizados, não estimulando o educando a desenvolver sua consciência crítica ${ }^{31}$. Essa metodologia de ensino, muitas vezes pode ser observada na Educação Continuada ${ }^{31}$.

No livro "Paulo Freire para Educadores", Barreto ${ }^{33}$ narra algumas percepções de Paulo Freire, e traz que, a educação é muito mais do que apenas memorizar, a educação é um ato de conhecimento, no qual o educador e o educando são considerados pessoas possuidoras de conhecimentos e capazes de aprender melhor através da participação ativa e do diálogo constante. Destaca também que a missão do educador é estimular o educando a problematizar a realidade concreta, e apropriarse da significação profunda do objeto, bem como compreender, pensar criticamente, buscar respostas e selecionar a mais adequada. $O$ educador deve valorizar o que 0 educando já sabe, a sua curiosidade, indagação e sua consciência do mundo ${ }^{33}$.

Desse modo, nessa percepção, antagônico a pedagogia da transmissão, a educação libertadora, problematizadora, não pode ser um ato de depositar, transferir conhecimentos e valores aos educandos, mas sim uma atividade transformadora da realidade ${ }^{31}$.

A educação problematizadora enfatiza a capacidade de o aluno identificar problemas em sua realidade e propor soluções para os mesmos em busca da transformação da realidade problemática. A relação entre alunos e docentes é 
horizontal, ambos aprendem e ensinam por meio de suas experiências e vivências, e parte do interesse dos próprios indivíduos ${ }^{31}$.

Nessa concepção, o educador já não é mais o que apenas educa, mas o que, enquanto educa, é educado, em diálogo com o educando, que enquanto está aprendendo, também está ensinando. Sendo essa metodologia pedagógica a que mais se aproxima dos princípios e diretrizes da EPS ${ }^{31}$.

Dessa forma, do ponto de vista pedagógico, sugere-se a revisão das práticas didáticas, a fim de superar a fórmula pedagógica que prevalece nas capacitações tradicionais, substituindo métodos com fulcro exclusivamente na transmissão de conhecimentos, por outros que permitam a problematização e o diálogo de situações cotidianas, considerando a dinâmica das rotinas do processo de trabalho ${ }^{6,26,34}$.

Sugere-se discutir as possibilidades de inserir metodologias ativas de ensino e aprendizagem dentro do contexto de EPS, aproximando a formação dos profissionais do SUS das reais necessidades do sistema, da clínica ampliada e do trabalho em equipes multiprofissionais e transdisciplinares, assim como metodologias de avaliação da aprendizagem ${ }^{6,26,34}$.

Em suma, apesar de ser notória a importância da metodologia de ensino aplicada nos processos de EPS, a metodologia, ainda é considerada um elemento crítico para a mudança na formação dos profissionais da saúde, uma vez que é necessário superar as concepções tradicionais de educação para que sejam levadas adiante as práticas inovadoras e ativas nos processos de EPS ${ }^{6}$.

\subsection{A EDUCAÇÃO A DISTÂNCIA COMO FERRAMENTA FACILITADORA DA EDUCAÇÃO PERMANENTE EM SAÚDE}

A qualificação profissional dos trabalhadores do SUS deve ser constante e, nesse contexto, com a necessidade de se estimular os processos de EPS e qualificação da formação dos recursos humanos para o SUS por meio de cursos de especialização e outras modalidades de formação, e considerando as dificuldades enfrentadas por profissionais de saúde que atuam em diversas áreas do saber, com relação ao acesso à formação continuada, viu se na Educação a Distância $(\mathrm{EaD})$ uma 
importante estratégia para a operacionalização e como um facilitador da EPS para os profissionais de saúde ${ }^{25,35}$.

A EaD pode ser considerada e definida como uma modalidade de ensino que facilita a autoaprendizagem, autoformação, autogestão com a ajuda de recursos didáticos organizados, apresentados em diferentes suportes de informação, e que pode ser utilizada por diversos meios de comunicação ${ }^{35}$.

Ela ainda torna efetiva, quanti-qualitativamente, a intervenção e otimização da formação, uma vez que, facilita a aprendizagem na própria unidade de trabalho sem afastar os profissionais por muito tempo das suas atividades, pois admite certa flexibilidade nos horários dedicados ao estudo, e poderá acontecer através de teleconferência ou videoconferência, com total interatividade, bem como, disponibilizando um arsenal de recursos multimídia ${ }^{35}$.

As metodologias de $\mathrm{EaD}$ incluem aprendizado independente, aprendizado aberto, televisão interativa, teleconferências, programa de pesquisa e programas nacionais ${ }^{35}$.

Como ferramentas para a EaD poderão ser utilizadas a internet, a digitalização e manipulação de imagens em CD-ROM ou fitas de vídeo, material impresso apoiado por transmissão em televisão, fitas de vídeo e áudio, orientação por computador, videoconferências, teleconferências, correio eletrônico, orientações presenciais e por correspondência entre outros recursos ${ }^{35}$.

No Brasil, o marco regulatório da EaD é a Lei de Diretrizes e Bases da Educação Nacional - Lei no. 9394, aprovada em 20 de dezembro de 1996, a qual estabelece as diretrizes e bases da educação nacional e inseriu a modalidade como regular e integrante do sistema educacional nacional, na qual em seu art. 80 reforça que o Poder Público deverá incentivar o desenvolvimento e a veiculação de programas de ensino a distância, em todos os níveis e modalidades de ensino, e de Educação Continuada ${ }^{36}$. Nova regulamentação foi publicada em 25 de maio de 2017, através do Decreto no $9.057^{37}$.

O Decreto $n^{\circ} 9.057$ de 25 de maio de 2007, regulamenta 0 art. 80 da Lei $n^{\circ}$ 9394, de 20 de dezembro de 1996 , que estabelece as diretrizes e bases da educação nacional, e traz como pontos importantes a definição da EaD e seu processo organizativo ${ }^{37}$.

A utilização da EaD como estratégia facilitadora nos processos de EPS é um processo relativamente recente no Brasil. Somente em 1998 foi criada a Escola de 
Educação a Distância da Escola Nacional de Saúde Pública Sérgio Arouca da Fundação Oswaldo Cruz (FIOCRUZ), considerada pioneira na oferta de cursos voltados para os profissionais da saúde ${ }^{25}$.

Por parte do Ministério da Educação, houve a criação do Sistema Universidade Aberta do Brasil - UAB, voltado para o desenvolvimento da modalidade de Educação a Distância através do Decreto № 5.800, de 8 de junho de 2006, que dispõe sobre 0 Sistema Universidade Aberta do Brasil - UAB ${ }^{38}$.

Em 2010, foi instituída o Sistema Universidade Aberta do Sistema Único de Saúde (UNA-SUS) no âmbito do Ministério da Saúde, por meio do Decreto oㅜ 7.385, de 8 de dezembro de 2010, com o objetivo de atender às necessidades de capacitação e Educação Permanente dos profissionais atuantes no SUS, mediante a oferta de cursos e programas de especialização, aperfeiçoamento e outras espécies de qualificação dirigida aos trabalhadores, sendo desenvolvidas através da modalidade de Educação a Distância ${ }^{39}$.

A Universidade Aberta do SUS pode ser considerada um canal facilitador para a EPS e para a estratégia de aprendizagem, uma vez que, com a oferta de cursos na modalidade a distância, propiciou o acesso dos profissionais a esses cursos, principalmente os das regiões mais afastadas do país ${ }^{40}$.

Esse projeto do Ministério da Saúde oferece cursos na modalidade a distância com enfoque prático e dinâmico, utilizando metodologias baseadas na integração ensino-serviço, tal como preconiza a PNEPS ${ }^{40}$.

Assim, a Educação Permanente ao ser realizada por meio da Educação a Distancia apresenta-se como uma possibilidade de democratização, por conseguir romper barreiras territoriais e temporais, uma vez que se tem acesso às tecnologias de comunicação e informação para o desenvolvimento profissional e humano, através do uso de mídias variadas, facilitando o acesso geográfico, com custo baixo, oferecendo a oportunidade para produção do dialogo e cooperação entre os profissionais dos serviços, atenção, formação e controle social ${ }^{35}$.

Vale aqui ressaltar que a EaD é um meio significativo e apropriado para atender a grandes contingentes de alunos de forma mais efetiva que outras modalidades e ainda é relevante desmistificarmos o pragmatismo de que a EaD seja um caminho mais barato, que atinge rapidamente a um número maior de trabalhadores e fazermos da EaD um caminho real de socialização de conhecimentos, de democratização dos bens culturais e técnicos produzidos pela sociedade e da formação do cidadão ${ }^{35}$. 





\section{PROPOSIÇÃO}

O objetivo geral deste estudo foi o de descrever e analisar o processo de planejamento e organização das ações de Educação Permanente em Saúde no município de Registro, Estado de São Paulo, correlacionando-o com as legislações pertinentes em vigor no período do estudo e como produto educacional, apresentar propostas que venham a colaborar para o incremento das ações que compõem 0 Plano Municipal de Educação Permanente. 



\section{METODOLOGIA}

\subsection{O CENÁRIO DA PESQUISA}

O estudo foi realizado no município de Registro, localizado na região do Vale do Ribeira, interior de São Paulo, considerada uma das mais pobres do estado.

O Vale do Ribeira é uma região localizada no sul do estado de São Paulo e no leste do estado do Paraná. Considerando a região do estado de São Paulo, o Vale é formado por 23 municípios, desses, 16 municípios são considerados de pequeno porte I (até 20.000 habitantes), 6 municípios são considerados de pequeno porte II (de 20.001 a 50.000 habitantes) e apenas Registro é considerado um município de médio porte (50.001 a 100.000 habitantes), com uma população estimada em 56.430 habitantes pelo Instituto Brasileiro de Geografia e Estatística (IBGE) em 201741,42,43. Desses, 12 municípios possuem Índice de Desenvolvimento Humano Municipal (IDHM) médio (de 0,600 e 0,699) e 11 municípios possuem IDHM alto (entre 0,700 e 0,799 ), incluindo Registro, que possui um IDHM de 0,75441,42.

O município de Registro é sede do Departamento Regional de Saúde (DRS) XII, que é responsável por coordenar as atividades e promover a articulação intersetorial no âmbito regional e municipal, e sua locorregião compreende 15 municípios: Barra do Turvo, Cajati, Cananéia, Eldorado, Iguape, Ilha Comprida, Iporanga, Itariri, Jacupiranga, Juquiá, Miracatu, Pariquera-Açu, Pedro de Toledo, Registro, Sete Barras ${ }^{44}$.

O mapa apresentado na Figura 4.1 mostra a divisão do Estado de São Paulo nos 17 Departamentos Regionais de Saúde existentes, com destaque à localização do DRS XII- Registro45. 
Figura 4.1-Mapa do Estado de São Paulo, segundo os Departamentos Regionais de Saúde, 2012

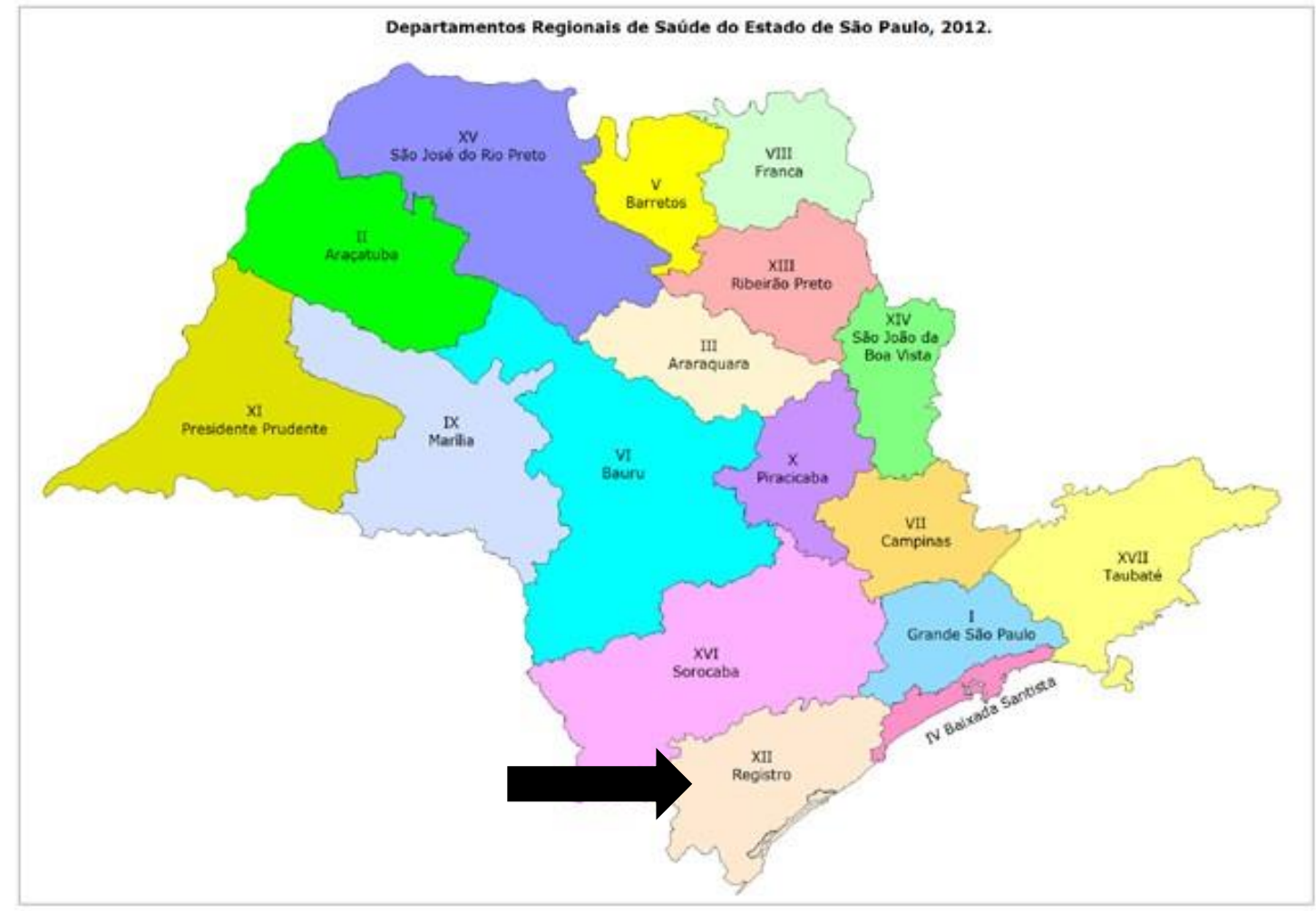

Fonte: Secretaria de Estado de Saúde ${ }^{45}$.

O município de Registro possuía, em 2018, 19 equipes de Estratégia de Saúde da Família (ESF), cada uma delas sediada em uma Unidade de Saúde da Família (USF), que cobriam aproximadamente 94\% da população. Até o final do ano de 2018 existia a perspectiva de entregar mais duas unidades de ESF, em distritos distintos, mas por questões burocráticas não ocorreu e o projeto segue em 2019.

A rede pública municipal de saúde de Registro contava também com as seguintes unidades e serviços: uma Secretaria Administrativa de Saúde; três Unidades Básicas de Saúde (UBS); uma Unidade de Vigilância em Saúde, que abriga a vigilância sanitária e epidemiológica; um Centro de Atenção Psicossocial (CAPS I); uma Unidade de Pronto Atendimento (UPA): um Núcleo de Apoio à Saúde da Família (NASF) modalidade I; um Centro de Especialidade Odontológica (CEO); um Centro de Especialidade Médica (CEM) e um Centro de Fisioterapia.

Complementarmente, o município é sede do Hospital São João, do Hospital Regional e do Centro de Referência em Saúde do Trabalhador (CEREST), todos de responsabilidade do Estado. 
Com o objetivo de melhor administrar a rede de atenção, planejamento e gestão da Saúde, organizou-se a assistência em três regiões, denominadas Distritos de Saúde, identificados pelas distintas cores e números no mapa da Figura 4.2.

Figura 4.2 - Mapa do município de Registro-SP com a localização dos Distritos de Saúde, 2018

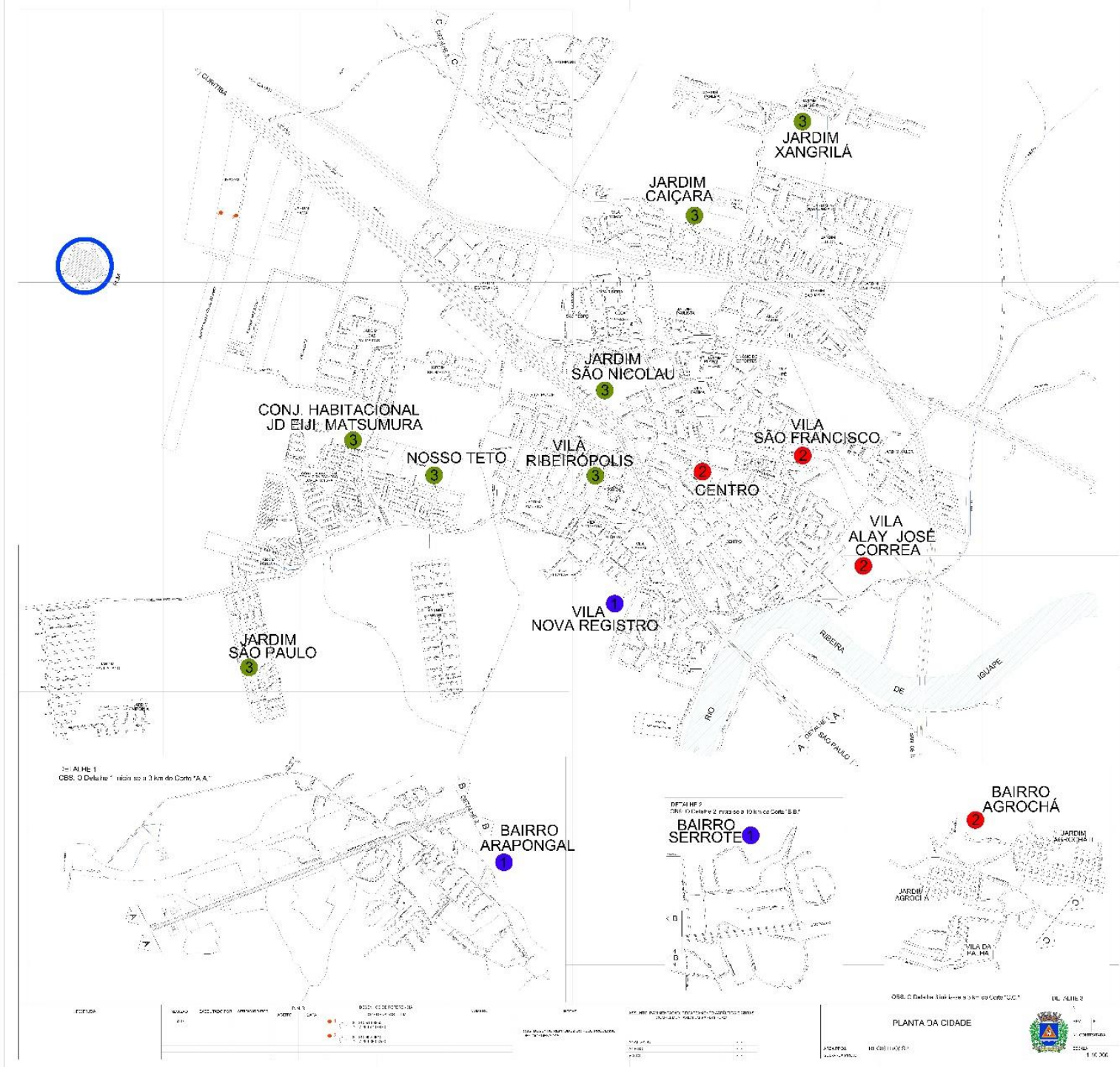

Fonte: SMS, Registro.

O Distrito 1 conta com cinco ESF (Vila Nova-Jacatirão, Vila Nova-Manoel Camilo, Arapongal, Arapongal Oeste e Serrote), o Distrito 2 possui sete ESF (Centro I e II, Agrocha, Alay Corrêa, Capinzal, Vila São Francisco e Votupoca), assim como o Distrito 3 (Registro B, Nosso Teto, Caiçara, São Nicolau, Jardim São Paulo, Ribeiropolis e Xangrila). Cada Distrito de Saúde, conta ainda com uma Unidade 
Básica e Distrital de Saúde (UBDS) que, além do atendimento básico para sua área de abrangência, será a referência de algumas especialidades para todo o distrito.

\subsection{DESENVOLVIMENTO METODOLÓGICO}

O presente estudo seguiu as normas para pesquisas com seres humanos, de acordo com a Resolução do Conselho Nacional de Saúde oㅡ 466/12 e somente foi iniciado após a aprovação pelo Comitê de Ética em Pesquisa da Faculdade de Odontologia da Universidade de São Paulo, com o parecer de número 2.701.759 (Anexo A). Aos participantes da pesquisa foi solicitada a assinatura do Termo de Consentimento Livre e Esclarecido (TCLE) (Apêndices A e B).

O período da coleta dos dados, obtidos pelas entrevistas, ocorreu de junho a agosto de 2018.

Para o desenvolvimento do estudo, tendo como referencial a proposta de avaliação de programas e serviços elaborada por Deslandes ${ }^{13}$, foram realizadas as seguintes etapas

1) Conhecimento aprofundado do objeto de análise. Essa fase, eminentemente descritiva, buscou conhecer a experiência da EPS no município: os principais objetivos institucionais, os dados estatísticos já produzidos pelo município, estratégias e dinâmica de desenvolvimento da Educação Permanente em Saúde, características da população-alvo, capacidade de cobertura e utilização, recursos utilizados.

Essa fase, além da caracterização, também possibilitou ao pesquisador a percepção inicial das propostas da Educação Permanente executadas no município, quer tenham sido organizadas pela própria Secretaria Municipal de Saúde (SMS), por outras instâncias de gestão ou outras iniciativas.

Nessa etapa foi realizada uma análise documental, com o objetivo de conhecer a experiência da EPS do município. Para complementar, foi realizada uma entrevista estruturada, direcionada ao responsável pela EPS no município, por meio de um questionário estruturado, desenvolvido a partir da cartilha do Ministério da Saúde sobre a Política Nacional de Educação Permanente em Saúde ${ }^{7}$ (Apêndice C).

No referido questionário, as perguntas foram montadas por blocos, com a pretensão de conhecer como é a organização e planejamento da Educação 
Permanente em Saúde no município, bem como a aplicação dessa e o processo de avaliação das ações realizadas.

A entrevista foi realizada na Secretaria Municipal de Saúde em um horário previamente agendado, de acordo com a conveniência do entrevistado. A mesma foi gravada mediante autorização, após a leitura e assinatura do TCLE e levou aproximadamente 50 minutos.

2) Análise da correlação entre projeto institucional e políticas públicas vigentes. Essa fase buscou analisar, em nível estrutural, a correlação existente entre o projeto institucional da EPS no município e as racionalidades técnicas e políticas que sustentam o projeto, bem como as contradições que vivencia.

3) Conhecimento empírico da atuação que se avalia. Como essa fase dependeria da realização de atividades relacionadas à Educação Permanente durante o período de realização do estudo para a participação e observação em campo, na busca por conhecer a prática da EPS no município, não foi possível efetivá-la, uma vez que não houve um momento oportuno para realizar a observação empírica no município.

4) Análise das representações sociais do público-alvo. Essa fase buscou compreender os valores, opiniões e visões acerca da Educação Permanente em Saúde. Entende-se que a tarefa de compreensão das expectativas, aspectos culturais e ideológicos do público alvo é crucial para analisar os "nós górdios", as possibilidades de sucesso e os pontos de (não) adesão e resistência e ainda promover uma aproximação da pesquisa com a realidade da prática assistencial.

Assim, o público-alvo para tal etapa foi composto pelos coordenadores dos distritos de saúde, por profissionais que atuavam na Estratégia Saúde da Família e no Núcleo de Apoio à Saúde da Família. O processo de seleção da amostra, assim como a estratégia para a coleta dos dados será descrita a seguir:

a) Coordenadores dos três distritos:

Participaram dessa etapa os coordenadores dos três distritos que compõem a divisão administrativa da saúde no município, bem como o responsável pela EPS.

Para conduzir a coleta de dados com os coordenadores dos distritos foi realizada a técnica do grupo focal.

Para a realização da referida técnica coube ao pesquisador á criação de um ambiente favorável à discussão, que propiciasse aos participantes manifestar suas percepções e pontos de vista ${ }^{46}$. 
O grupo focal deve ocorrer em espaços apropriados, de preferência em território neutro e de fácil acesso aos participantes, que pode variar de seis a quinze pessoas $^{46}$.

Embora o número de participantes (quatro), esteja aquém do que é sugerido para o grupo focal, optou-se pelo uso por considerar ser uma metodologia que propicia um diálogo entre os participantes, no qual todos consideram as opiniões do grupo para formular a própria. A adoção da técnica, como uma de investigação qualitativa, tem como objetivo coletar informações, apreender percepções, opiniões e sentimentos frente a um tema determinado, por meio da discussão participativa entre os participantes, reunidos em um mesmo local durante certo período, a fim de obter os dados necessários à pesquisa ${ }^{46}$.

A determinação do tempo necessário para a condução do grupo focal depende de alguns fatores, como o número de participantes e a complexidade do tema, contudo, uma variação entre 90 (tempo mínimo) e 110 minutos (tempo máximo) deve ser considerada para um bom emprego da técnica ${ }^{46}$.

Assim, o objetivo desse grupo focal foi o de conhecer as percepções e o envolvimento dos coordenadores para o planejamento e organização das propostas de Educação Permanente no município, levando em consideração as especificidades de cada região. Para tanto, foi proposto um roteiro, previamente elaborado, com temas para nortear a discussão no grupo (Apêndice D).

A realização do grupo focal ocorreu na SMS, coincidindo com a data e horário da reunião semanal de coordenadores de distrito. Teve duração média de 30 minutos e foi gravado, mediante a autorização previa dos mesmos, após a leitura e assinatura do TCLE.

b) Profissionais atuantes no Núcleo de Apoio à Saúde da Família:

Para compor a amostra desse grupo foram convidados dois profissionais do NASF, independentemente da categoria, mas que já estivessem atuando no município há pelo menos três anos e que tivessem realizado algum curso de EPS oferecido em parceria pelo Ministério da Saúde.

c) Profissionais atuantes na Estratégia Saúde da Família:

A seleção dos participantes também se deu por meio de um convite intencional para dois profissionais de cada distrito, portanto, seis indivíduos, entre médicos, enfermeiros e cirurgiões-dentistas. Como critérios de inclusão foram sugeridos aqueles que atuavam no município há pelo menos três anos e que já tivessem 
realizado algum curso de EPS oferecido em parceria pelo Ministério da Saúde. Foi possível conseguir uma homogeneidade no número de participantes de cada categoria profissional.

Para a coleta de dados com os profissionais atuantes no NASF e na ESF foram realizadas entrevistas individuais, a partir de um roteiro de questões estruturadas (Apêndice E). As entrevistas ocorreram no próprio ambiente de trabalho dos profissionais, em data e horário mais conveniente aos mesmos; tiveram duração média de 40 minutos e foram gravadas com a autorização prévia dos entrevistados, após a leitura e assinatura do TCLE.

Tanto para o grupo focal como para as entrevistas individuais a gravação teve o objetivo de facilitar a transcrição integral das informações obtidas para então serem analisadas.

A metodologia escolhida para a análise de dados da pesquisa foi à técnica de análise de conteúdo temática proposta por Bardin, que traz três fases principais: préanálise, exploração do material e tratamento dos resultados, inferência e interpretação ${ }^{47}$.

Iniciou-se pela fase de organização propriamente dita, nomeada de préanálise, que compreende a leitura geral do material transcrito das entrevistas. Essa etapa é composta pela leitura flutuante, a escolha dos documentos obedecendo às orientações das regras da exaustividade, representatividade, homogeneidade e pertinência, a formulação de hipóteses e objetivos e a preparação do material $47,48,49$.

Em seguida, realizou-se a exploração do material, que constitui a segunda fase, no qual foram realizados recortes dos textos em unidades de registro e a classificação e agregação das informações em categorias temáticas ${ }^{47,48,49}$.

E, para finalizar, foi realizado tratamento dos resultados brutos, inferência e interpretação, com os objetivos de se tornarem válidos e significativos ${ }^{47,48,49}$.

Como última etapa para a avaliação de programas, Deslandes ${ }^{13}$ propõe uma quinta fase. 
5) Análise propriamente dita. Essa, foi de confecção do relatório/diagnóstico. Buscou-se articular as informações obtidas com os conhecimentos teóricos sobre a temática, visando propor ações (técnicas/políticas). Outra perspectiva importante será o compromisso de compartilhar o conhecimento produzido com aqueles sujeitos envolvidos cujas ações e vivências serão objeto de reflexão. 


\section{RESULTADOS E DISCUSSÃO}

De acordo com a proposta metodológica para a avaliação de serviços e projetos de saúde elaborada por Deslandes ${ }^{13}$, tomou-se como ponto de partida a observação da realidade.

Compuseram o corpus para análise temática todo o material transcrito das entrevistas, realizadas entre julho e agosto de 2018, os textos legislativos e dados municipais disponibilizados pela Secretaria Municipal de Saúde, sendo o resultado apresentado por temas e discutidos a partir do diálogo com a literatura científica.

\subsection{A EXPERIÊNCIA DA EDUCAÇÃO PERMANENTE EM SAÚDE NO MUNICÍPIO}

\subsubsection{Sobre os fluxos Normativos}

Consta na PNEPS (2009), que todo município deve formular e promover a gestão da EPS e processos relativos à mesma ${ }^{7}$, sendo assim, para se promover a discussão das propostas de EPS desenvolvidas pelo município de Registro, buscouse inquerir sobre os diferentes enfoques que orientavam as ações de planejamento e desenvolvimento da EPS no município mediante entrevista com o responsável pela EPS.

É pertinente aqui citar que, no ano de 2018, Registro possuía o cargo de responsável pela Educação Permanente em Saúde no organograma da SMS, e as atribuições de planejar, organizar e fornecer apoio às ações relativas à EPS no município dependiam de uma pessoa que ocupasse o cargo, sem a existência de um setor próprio.

Esse dado corrobora com a realidade do Estado de São Paulo pois, dos 357 municípios avaliados no documento do Plano Estadual de Educação Permanente em Saúde do estado de São Paulo (PEEPS) (2019), 43,1\% (154) contavam com apenas uma pessoa responsável e não um setor. $O$ estudo ainda revelou que quase um quarto 
(22,7\%) dos municípios (81) não possuía qualquer estrutura organizada ou profissional específico para a EPS ${ }^{50}$.

É importante citar que uma das diretrizes do PEEPS se constitui na estruturação dos Núcleos de Educação Permanente em Saúde Municipais, que devem ser formados por técnicos dos municípios, denominados "facilitadores de Educação Permanente em Saúde", os quais teriam como principal atribuição, apoiar a detecção das necessidades dos municípios, bem como acompanhar o processo de desenvolvimento das iniciativas ${ }^{50}$.

O organograma abaixo retratado (Figura 5.1) sintetiza como é definida a estrutura dos colaboradores e a comunicação entre as partes, no planejamento da EPS em nível de Secretaria Municipal de Saúde. Esse esquema é uma simples demonstração e não necessariamente precisa ocorrer nessa ordem, uma vez que as questões a serem trabalhadas na EPS vão surgindo no agir do trabalho e a EPS pode acontecer na própria Unidade de Saúde, sendo realizado pelos próprios trabalhadores capacitados.

Figura 5.1 - Organograma com os colaboradores no planejamento da Educação Permanente em Saúde, de nível de Secretaria Municipal de Saúde, de Registro, 2018

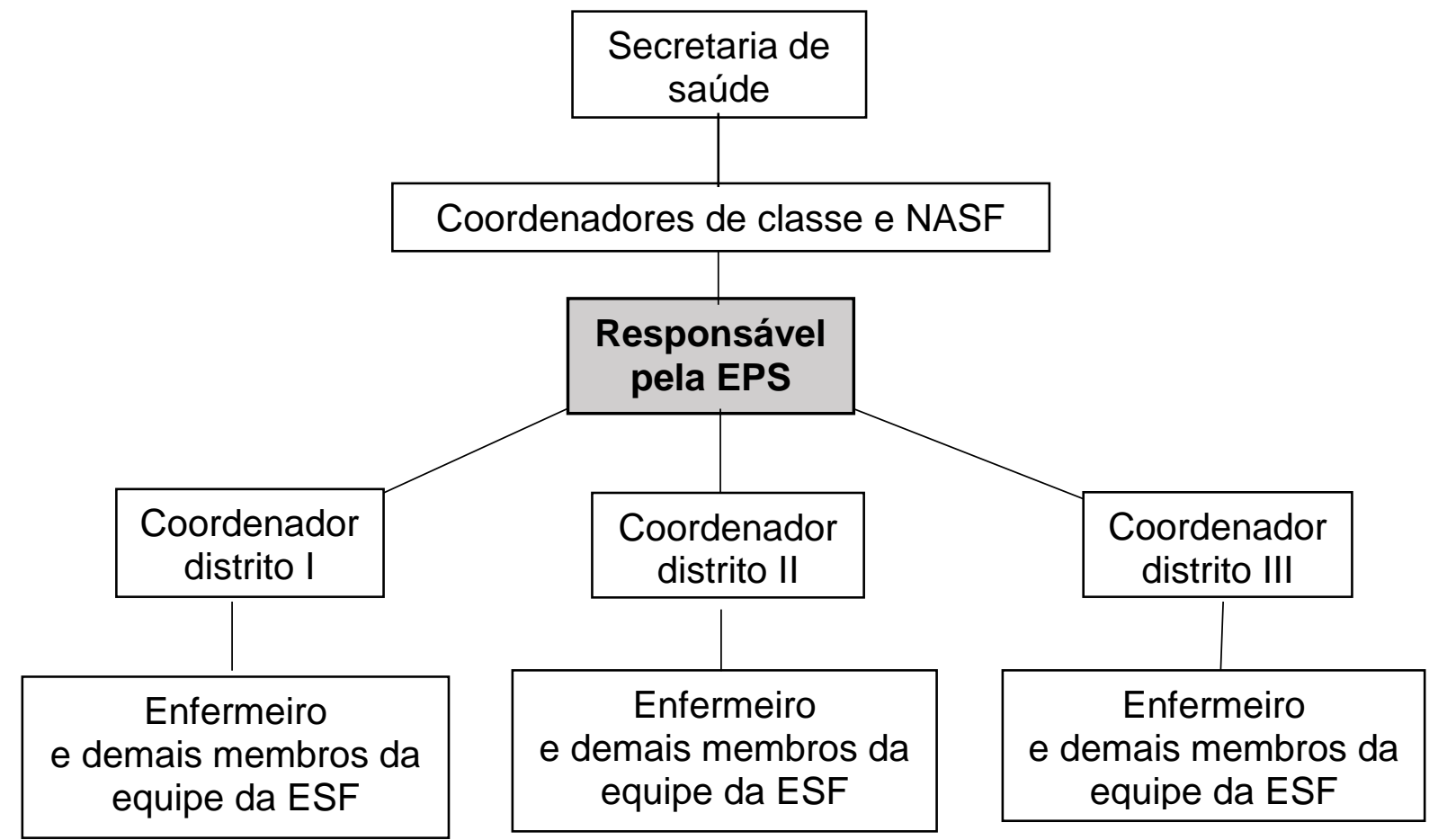

Fonte: SMS de Registro, elaborado pelo autor. 
Cada equipe de ESF é formada por: médico, enfermeiro (que também realiza a função de chefe administrativo da unidade), técnicos de enfermagem, Agentes Comunitários de Saúde (ACS), auxiliar administrativo, auxiliar de limpeza e das 19 unidades de ESF, 13 contam com o dentista e auxiliar de saúde bucal (ASB). Vale aqui dizer que existe o projeto, para o ano de 2019, da ampliação da equipe de saúde bucal, aumentando a cobertura.

Conforme o relato do responsável pela EPS, o processo de elaboração das ações de Educação Permanente se dá por meio dele e de colaboradores (coordenadores de distrito, coordenador da odontologia, coordenador da fisioterapia, profissionais do NASF, enfermeiros, ou mesmo os profissionais das Unidades de Saúde) com o intuito de que as ações tenham significado a todos os envolvidos.

Esse ainda cita que, parte das demandas vem dos coordenadores de distrito, uma vez que esses estão em constante contato com os trabalhadores das ESF mediante reuniões e são responsáveis, entre outras atribuições, por levar as demandas, dúvidas, problemas e necessidades de formação dos trabalhadores. Essas demandas, na maioria das vezes, são relatadas pelo enfermeiro chefe administrativo da unidade, que conhece a realidade enfrentada no dia a dia de sua equipe, bem como as experiências e dúvidas que essa tenha.

Tendo conhecimento das necessidades, o responsável pela EPS irá articular as propostas juntos dos colaboradores e, quando necessário, esses requerimentos são levados aos colaboradores da SMS no qual inclui também o Secretário de Saúde.

Essa organização é condizente com o material produzido pelo Ministério da Saúde "A Educação Permanente, Entra na Roda", que indica que, para provocar mudanças nos processos de formação, é preciso, entender, que as propostas não devem ser construídas isoladamente e nem de maneira hierárquica, ou seja, serem pensadas e decididas apenas pelos coordenadores, desconsiderando-se as realidades locais e necessidades individuais; mas devem ocorrer em todos os locais, envolvendo vários saberes ${ }^{5}$.

Cabe aqui destacar que a EPS deve se colocar como uma política estratégica do SUS, e deve ser pactuada entre os gestores do sistema e construída com a participação dos profissionais e usuários e, alicerçada em processos educacionais que incorporem novas tecnologias e modalidades de ensino e busquem parcerias com redes de apoio institucional ${ }^{50}$. 
O município de Registro não contava, até o momento da pesquisa, com uma Política Municipal de Educação Permanente em Saúde, entretanto o responsável pela EPS relatou que algumas pactuações são definidas e elaboradas em conjunto dos colaboradores da saúde e colocadas no Plano Municipal de Saúde (PMS), na Programação Anual de Saúde (PAS) e no Plano Plurianual (PPA). Esse último, disponível a todos os interessados, possui vigência de quatro anos, o que possibilitada que as propostas sejam trabalhadas durante a gestão vigente.

Ainda segundo o documento do Plano Estadual de Educação Permanente em Saúde (PEEPS), (2019), no estado de São Paulo, quase a totalidade dos municípios paulistas (cerca de 90\%) incluem suas necessidades e propostas de EPS no Plano Municipal e na Programação Anual de Saúde ${ }^{50}$.

Essa afirmação pode parecer contraditório ao que é proposto pela PNEPS a qual prevê que todo município deve formular e promover a gestão da EPS, responsabilizando-se por criar estruturas para a coordenação e execução das ações de EPS no município, bem como pela elaboração de uma Política de Educação Permanente em Saúde?

Para o responsável pela EPS as propostas elaboradas para a EPS dentro do Plano municipal de Saúde e do Plano Plurianual se baseiam no que é proposto dentro da PNEPS, uma vez que é considerada, entre outras, a demanda dos profissionais de saúde, assim como pode ser observado em sua fala:

"[...] é o processo de trabalho e é o que está acontecendo lá no local, então é dentro da demanda do profissional de saúde de cada local é que a gente faz a educação permanente [...]".

Essa percepção corrobora com o que traz a Portaria $n^{0} 1.996^{18}$, que cita que os processos de EPS devem ser planejados a partir das necessidades e problemas enfrentados na realidade do município e daquela equipe, considera as necessidades de formação e desenvolvimento dos trabalhadores, bem como os conhecimentos e as experiências que as pessoas já têm .

O responsável julgou ainda que a EPS devesse ser algo dinâmico, que surge no processo de trabalho, mas que ainda não é capaz de contemplar as questões de formação e desenvolvimento dos trabalhadores para o SUS, principalmente pela falta de conhecimento do que é Educação Permanente e de nomeá-la como tal, embora a EPS esteja presente no cotidiano do trabalho quando se realiza as reuniões semanais 
de equipes nas unidades e mensais com as categorias médicos, enfermeiros e dentistas na SMS e nos grupos com a comunidade.

Essa questão levantada corrobora com a expressão de Merhy ${ }^{51}$, ao citar que na roda de conversa muitas coisas podem acontecer e surgir independe do organograma oficial do serviço e da hierarquização da organização e, nesse acontecer, podem-se produzir novos conhecimentos efetivos, novos processos de formação e que impactem o modo de cuidado. E esse movimento pode ser visto, como um movimento de EPS, que ocorre ali no dia a dia, entre os vários atores que muitas vezes colaboraram, mas que não tem o conhecimento para nominar esse processo como tal.

O responsável pela EPS ainda destacou, que a falta de documentação das ações através de avaliações e monitoramento, assim como a ausência nas unidades, de um documento que facilite o entendimento dos profissionais sobre EPS, pode ser fatores que dificultem o entendimento e a devolutiva dos profissionais sobre suas percepções a cerca da EPS.

Entretanto, o município não está aquém da realidade do Estado de São Paulo em relação ao monitoramento e avaliação, uma vez que entre os Centros de Desenvolvimento e Qualificação para o SUS (avaliados) foi unanime o relato sobre a ausência de processos de monitoramento e avaliação das ações de EPS ${ }^{50}$. É pertinente citar aqui que os principais motivos relatados foram á falta de cultura avaliativa e insuficiência de recursos humanos ${ }^{50}$.

O responsável complementou que o que os profissionais mais desejam são cursos, entretanto, a prefeitura não disponibiliza muito esse recurso para os funcionários.

Essa percepção pactua com os achados em um estudo realizado por Bispo e Moreira $^{27}$, que afirma que o entendimento que vigora entre os colaboradores é que o modelo formativo deve acontecer a partir de cursos, treinamentos e capacitações com profissionais especialistas e em ambiente fora dos serviços de saúde.

O responsável pela EPS relatou que embora muitos desconheçam o termo, o desenvolvimento da EPS pelos municípios é um dos itens de avaliação do Programa de Melhoria do Acesso e da Qualidade (PMAQ) do Ministério da Saúde, que traz questões que buscam dimensionar as ações de EPS; se elas comtemplam as necessidades das equipes de saúde da atenção básica e se são elaborados com a 
participação dos profissionais. Todas as equipes cadastradas responderam esse instrumento de avaliação.

O Programa de Melhoria do Acesso e da Qualidade da Atenção Básica (PMAQAB) foi instituído através da Portaria ํㅡㄴ.654, de 19 de julho de $2011^{52}$, revogada pela Portaria $\mathrm{n}^{\circ}$ 1.645, de 01 outubro de 2015, e tem por objetivo induzir a ampliação do acesso e melhoria da qualidade da atenção básica, além de buscar garantir um padrão de qualidade e incentivo financeiro ${ }^{53}$.

A Portaria $n^{\circ} 2.812$, de 29 de novembro de 2011, homologa a adesão dos municípios e das respectivas equipes de atenção básica ao PMAQ-AB ${ }^{54}$.

$O$ instrumento de avaliação externa do PMAQ-AB investigou a EPS na Atenção Básica, principalmente, questionando sobre a participação, ações realizadas e quais tipos, se as ações de EPS contemplavam as necessidades da equipe, a utilização das possíveis ofertas de apoio do telessaúde, do telediagnóstico, da tele-educação ou da teleconsultoria. Ainda continha questões sobre o acolhimento de estudantes, professores, pesquisadores em atividades de ensino, pesquisa e extensão, e se as atividades desenvolvidas estavam articuladas com o processo de trabalho ${ }^{55}$.

$\mathrm{Na}$ primeira fase, em 2011, Registro aderiu com seis equipes ${ }^{54}$, na segunda com treze equipes de ESF e um NASF e para o terceiro ciclo do PMAQ-AB, o município contava com dezessete equipes de ESF cadastradas, e a maioria das equipes obtiveram notas entre muito bom e ótimo, podendo assim constatar que 0 município foi bem avaliado, inclusive no quesito Educação Permanente.

Bezerra e Medeiros $^{55}$ trazem que a concepção de EPS trabalhado no instrumento de avaliação externa do PMAQ-AB é limitada, uma vez que o instrumento poderia indicar com maior detalhamento, a realidade dos municípios. Salientam também a necessidade de uma análise mais apurada das diretrizes, dos princípios e questões mais aprofundadas sobre o desenvolvimento de EPS no trabalho voltadas as equipes e uma análise mais elaborada dessas iniciativas, favorecendo identificar a concepção de educação ofertada e sua capacidade de transformar o trabalho na Atenção Básica e fortalecer a prática de EPS nos municípios.

Vale aqui citar que se os entrevistados não conhecem e confundem os termos relacionados à EPS, assim, as respostas podem não terem sido com exatidão e clareza.

Dentro da proposta de EPS, o responsável citou que busca trabalhar principalmente os indicadores do município e as linhas de cuidado prioritárias, que 
são grupos condutores como, por exemplo, a Rede Cegonha, a Rede de Atenção Psicossocial (RAPS), Rede de Urgência e Emergência (RUE), Atenção à Saúde das Pessoas com Doenças Crônicas, gestantes, crianças menores de um ano e algumas solicitações dos trabalhadores.

Entretanto, ouvidos os demais profissionais sobre os temas em EPS com maior necessidade percebida, o que eles gostariam que fosse trabalhado dentro da EPS, foram temas relacionados ao processo de trabalho, saúde mental, saúde social, enfim, assuntos atualizados de acordo com as necessidades locais para aquele momento.

Embora contraditório, o texto "EPS em movimento", de 2014, já sinalizava que trabalhar os manuais e protocolos ajudam, mas não é suficiente para garantir a realização de um bom trabalho, isso porque o cotidiano de trabalho sempre apresenta imprevisto, que não estão descritos nos manuais. Dessa maneira quando se pensa no processo de educação em saúde, há que considerar essa imprevisibilidade do trabalho ${ }^{56}$.

Consta na Portaria $n^{\circ} 1.996$ (2007), que todo município deverá ter uma Comissão Permanente de Integração Ensino- serviço (CIES) de referência ${ }^{18}$. No caso de Registro essa comissão existe na DRS XII, local onde ocorrem as reuniões do Núcleo de Educação Permanente em Saúde e Humanização (NEPH), que é um núcleo de Educação Permanente regional, responsável pelo planejamento regional da EPS. Nessa instância as prioridades são definidas coletivamente, ou seja, o gestor de saúde e o responsável pela EPS do município levam as demandas para as reuniões, mas essas demandas devem coincidir com as demandas dos demais municípios pertencentes à DRS XII para poderem ser colocadas em prática. Quando uma questão é necessidade da maioria dos municípios pertencentes à DRS XII, é planejada alguma ação e são distribuídas vagas por município de acordo com o número de vagas disponíveis e o porte do município, o que acaba sendo insuficiente para a participação de todos os interessados.

Consta na PNEPS (2009), que todo município deve incentivar, junto à rede de ensino, no âmbito municipal, a realização de ações educativas em saúde relativas aos SUS, e também promover diretamente ou em cooperação com os estados e com os municípios da sua região, processos conjuntos de EPS ${ }^{7}$. Entretanto, o município não tem nenhuma parceria com os municípios da região e nem com alguma instituição de ensino. 
Mas, paralelamente, o município participa das atividades conjuntas dos profissionais da DRS XII. Sempre que necessita de algum apoio é solicitado algum profissional para desenvolver, junto ao município, alguma ação. Como exemplo, o responsável pela EPS citou as Oficinas de Atenção Básica, e as Mostras Exitosas de Experiências Municipais realizada no ano de 2016. O mesmo ainda citou que sempre buscou parcerias para trazer algum profissional de fora para palestrar de forma voluntária, uma vez que o município não tinha um recurso específico destinado para essas ações.

A propósito, no que diz respeito ao financiamento de ações de EPS no município, Registro não tinha uma verba especifica destinada a EPS, e não recebia, até então, nenhum recurso financeiro estadual e/ou federal. O recurso destinado a estas ações era recebido pela DRS XII, que era para ser gasto com todos os municípios pertencentes à DRS XII.

A partir do ano de 2018, com a nova Portaria $n^{\circ} 3.342$ de 7 de dezembro de $2017^{24}$, é que o município irá passar a receber um valor anual, mas que acredita ser insuficiente; até a data da pesquisa ainda não havia sido feito o repasse.

Com relação ao acompanhamento e avaliação das atividades de EPS já realizadas no município, não existia nenhum registro formal, embora esteja descrito na Portaria $n^{\circ} .1 .996^{18}$ a importância desse registro para 0 acompanhamento. Entretanto, já está sendo estudada uma maneira de monitorar essas ações e se pensa na criação de um instrumento para melhor registrar essas atividades.

\subsubsection{Sobre a Qualificação dos trabalhadores da Estratégia Saúde da Família}

Foi realizada uma consulta pela Secretaria Municipal de Saúde no ano de 2018 entre os profissionais de nível superior atuantes na Estratégia Saúde da Família (Tabela 5.1), quanto à conclusão de algum curso de especialização e, em caso afirmativo, levantou-se o tipo e identificação das respectivas instituições.

A tabela 5.1 mostra a distribuição dos servidores de nível superior, atuantes na ESF no ano de 2018. 
Tabela 5.1 - Número de servidores de nível superior atuantes na Estratégia Saúde da Família, segundo categoria profissional ou função. Registro, 2018

\begin{tabular}{l|l}
\hline Categoria ou Função & Número de profissionais \\
\hline Médico & 12 \\
Médico do programa Mais Médico & 7 \\
Cirurgião Dentista & 14 \\
Enfermeiro & 19 \\
Coordenador de Distrito & 3 \\
\hline Total & $\mathbf{5 5}$ \\
\hline
\end{tabular}

Fonte: SMS de Registro.

Devido ao número expressivo de médicos Cubanos, do Programa Mais Médicos (PMM) que atuavam nas unidades no período da pesquisa, foi realizada uma separação a fim de se considerar as especializações desses profissionais realizadas em outro país, mesmo que esses não pudessem exercê-la no Brasil, mas partindo do pressuposto de que todo conhecimento adquirido é importante no desempenho da medicina de família.

O Programa Mais Médicos foi instituído no país através da Lei oํ 12.871, de 22 de outubro de 2013 e foi uma alternativa que o Governo Federal encontrou para atender as demandas dos municípios, principalmente os mais distantes e vulneráveis 57 .

No programa, é prevista a EPS dos profissionais por meio da Universidade Aberta do Sistema Único de Saúde (UNA-SUS), que oferta cursos de aperfeiçoamento e de especialização na modalidade a distância, a fim de facilitar o processo de formação profissional na área da saúde ${ }^{40,57}$.

A realização do curso era uma etapa obrigatória para a permanência do médico no programa, esses, deviam cumprir um total de 40 horas semanais, sendo 32 horas para atividades clínicas e oito horas para a realização de cursos de aperfeiçoamento e/ou especialização com temáticas definidas pelo Ministério da Saúde 40,57.

Com relação ao período semanal destinado para a realização de cursos, um dos entrevistados trouxe um importante questionamento ao indagar o porquê de os médicos do Programa Mais Médicos ter uma política que os asseguram o benefício de estudar e o mesmo não ocorrer para os demais profissionais. 
Registro contava na época da pesquisa com sete médicos do PMM, e todos relataram ter realizado ou estar realizando o curso de especialização Saúde Da Família ofertado pela UNA-SUS.

Cabe destacar que os dados foram levantados antes do governo cubano anunciar, em novembro de 2018, sua retirada e a ruptura do convênio com o governo brasileiro, já que os médicos do Programa Mais Médicos atuantes no município eram cubanos.

Vale aqui mencionar que o município continua com profissionais do programa, entretanto são médicos formados em instituições de educação superior brasileira ou com diploma revalidado no Brasil (CRM Brasil), ou com habilitação para exercício da medicina no Brasil.

Sobre a presença de profissionais com cursos de pós-graduação, verificou-se que a maioria deles possuía pelo menos um curso de especialização concluído (Figura $5.2)$.

Figura 5.2 - Profissionais de nível superior atuantes na Estratégia Saúde da Família segundo formação pós-graduação, 2018

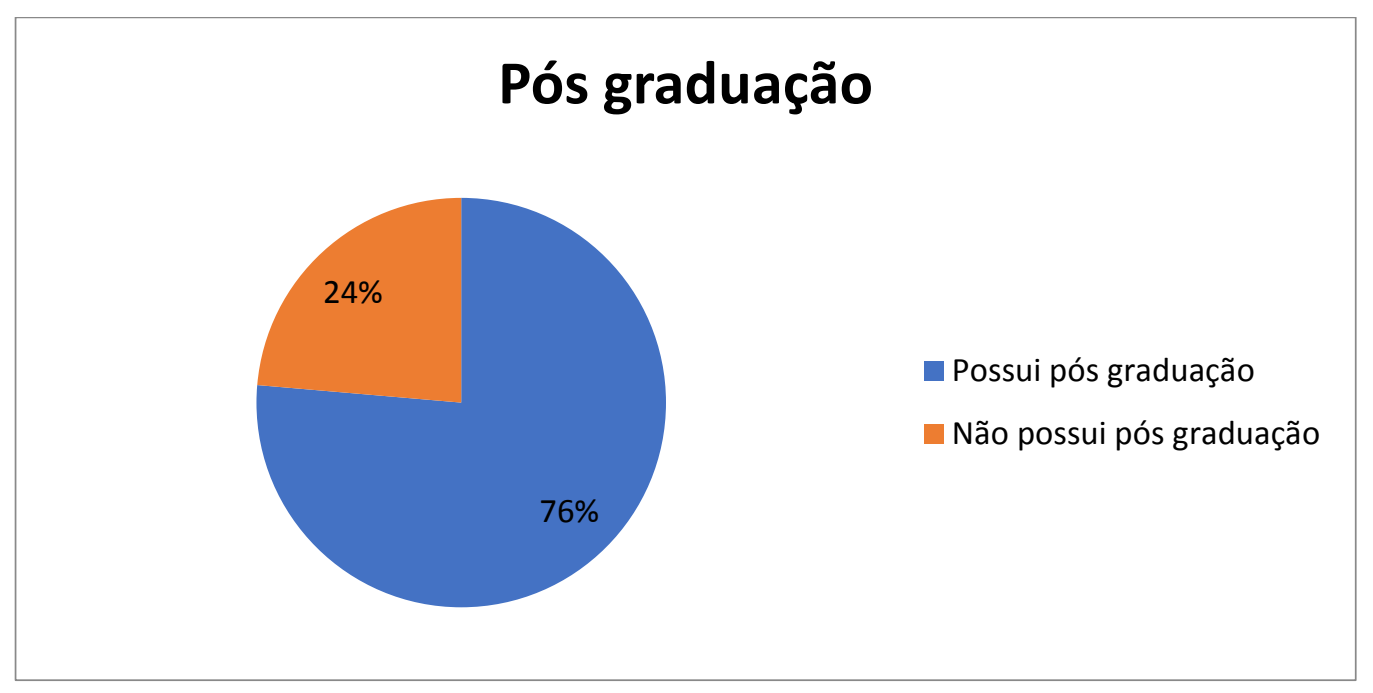

Fonte: SMS Registro.

Quanto ao tipo de instituição de nível superior cursada, se pública ou privada, para os cursos de especialização, pode-se observar equilíbrio na distribuição, conforme a tabela 5.2 . 
Tabela 5.2 - Tipo de instituição de nível superior dos cursos de especialização cursados por profissionais da saúde. Registro, 2018

\begin{tabular}{l|l}
\hline \multicolumn{1}{c|}{ Categoria } & \multicolumn{1}{c}{ Número } \\
\hline Instituição Pública & 36 \\
Instituição Privada & 39 \\
Instituição Pública Internacional (Cuba) & 6 \\
\hline Total & $\mathbf{8 1}$ \\
\hline
\end{tabular}

Fonte: SMS de Registro.

Dos 36 cursos de especialização em alguma instituição pública de ensino superior, a mais frequente foi a Universidade Federal de São Paulo-Unifesp (25), seguida pela Fundação Oswaldo Cruz-FIOCRUZ (5) e outras instituições (6), assim como é possível verificar na figura 5.3.

Figura 5.3 - Distribuição das instituições públicas de ensino superior dos cursos de especialização realizados pelos profissionais da saúde de nível superior atuantes na Estratégia Saúde da Família, 2018

\section{Instituição pública de Ensino Superior}

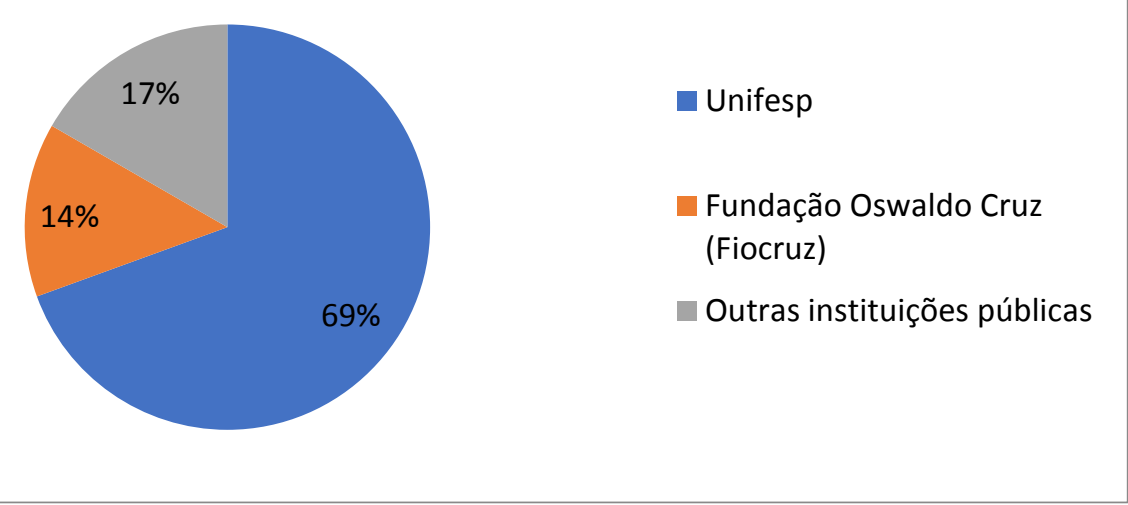

Fonte: SMS, Registro. 
Desses, o curso mais citado pelos profissionais foi a especialização em saúde da família oferecida pela UNASUS/UNIFESP, obrigatória para os médicos do Programa Mais Médicos, mas também permitida a outros profissionais; especialização em saúde pública, saúde coletiva, medicina da família e comunidade e outras formações relacionadas ao trabalho no serviço público de saúde.

Em virtude do elevado número de profissionais com pós-graduação, em especial ás públicas, gerou-se a expectativa de que os entrevistados conhecessem as propostas da EPS, entretanto não foi a realidade encontrada nas entrevistas.

Dentre os cursos citados, alguns foram realizados na modalidade $\mathrm{EaD}$, ressaltando a importância dessa ferramenta para a EPS, uma vez que ela facilita 0 acesso.

Assim, foi possível observar que a maioria dos profissionais de nível superior possuem algum curso de especialização, uma vez que, dos 55 profissionais, apenas 13 não possuíam nenhuma especialização concluída.

Alguns profissionais citaram ainda as capacitações gratuitas realizadas na modalidade EaD sobre temas importantes da Atenção Básica fornecidas por diversas instituições públicas sendo possível observar a utilização dos recursos que vêm sendo disponibilizados pelo Ministério da Saúde às equipes de Atenção Básica, como é o exemplo do telessaúde, e mesmo os profissionais entrevistados terem participado de cursos do MS, os mesmos desconhecem a EPS.

Considerando os entrevistados nesta pesquisa, todos citaram querer continuar estudando e se capacitando conforme forem surgindo as oportunidades, uma vez que todo novo aprendizado acrescenta algo no processo de trabalho, sendo considerado muito importante para a prática.

Na PNEPS (2009) consta que todo município deve incentivar, junto à rede de ensino, no âmbito municipal, a realização de ações educativas e de conhecimento do SUS, e o Plano Municipal de Saúde deve contemplar as questões da formação e desenvolvimento dos trabalhadores para o SUS ${ }^{7}$.

Sobre as necessidades de qualificação, o responsável pela EPS relatou que utiliza como estratégia estimular os profissionais de nível superior a realizar os cursos de capacitações e especializações na modalidade EaD ofertados pelo Ministério da Saúde, para os quais sempre são avisados acerca dos processos seletivos, uma vez que o município não os oferece. 
Em contrapartida, a prefeitura incentiva os profissionais a participarem desses processos educativos por meio da liberação do profissional para realizar os cursos e, quando possível, existe um auxílio financeiro para a alimentação, hospedagem e transporte.

Entretanto, dos profissionais entrevistados que compuseram os atores representantes das ESF (total de seis participantes), ao serem indagados sobre a viabilidade de realizar atividade de EPS no município, as respostas dos profissionais da assistência não foram homogêneas entre as categorias quanto à liberação, alguns acreditam que essa seja uma questão política administrativa e que dependa muito de a gestão vigente liberar ou não o profissional.

Carotta et al. ${ }^{58}$ também destaca como um dos facilitadores para a institucionalização da EPS o comprometimento e sensibilização do gestor com a estratégia da EPS considerado um dos pilares para o fortalecimento da EPS nas unidades de saúde.

A PNEPS (2009) prevê também a formação dos profissionais de nível técnico, indicando que o município deve promover e articular junto às escolas técnicas de saúde uma orientação para a formação de profissionais técnicos para o SUS ${ }^{7}$.

No estado de São Paulo, existem seis Escolas Técnicas do SUS (ETSUS), que são os seis centros formadores de pessoal da SES-SP, a saber: Franco da Rocha, Assis, Pariquera - Açu, Osasco, Araraquara e São Paulo. Esses centros têm a finalidade de qualificar, habilitar e especializar trabalhadores do SUS com escolaridade equivalente aos níveis fundamental e médio, por meio da Educação Profissional, atendendo às necessidades dos Gestores de Saúde, encaminhadas pelas Comissões Intergestora Regional, bem como atender às necessidades de qualificações profissionais ao cumprimento das ações propostas pela SES e pelo $\mathrm{MS}^{50}$.

No município de Registro, a oferta de formações para profissionais de nível técnico é menor, no entanto, existe na região o Centro de Formação de Recursos Humanos de Pariquera-Açu (CEFORH), em convênio com vinte e seis municípios do Vale do Ribeira, que repassa recursos e encargos financeiros ao Consórcio Intermunicipal de Saúde do Vale do Ribeira (CONSAÚDE). Esse, atende as necessidades de formação de trabalhadores de saúde, seja das unidades básicas, unidades ambulatoriais e hospitalares de variados graus de complexidade ${ }^{59}$. 
Como opções de oferta de cursos citam-se o curso de formação inicial de Agente Comunitário de Saúde e o curso de Auxiliares em Saúde Bucal, cujos trabalhadores participantes do município realizam as aulas na Secretaria Municipal de Saúde ${ }^{59}$.

Uma questão importante levantada sobre formação é a falta de capacitações com o intuito de qualificar novos e antigos profissionais que são recolocados em novos cargos dentro da prefeitura uma vez que, ao assumirem, já vão direto para o serviço, sem o conhecimento do funcionamento do sistema e da realidade.

No olhar do responsável pela EPS no município, essa capacitação não existe, pois se imagina que os profissionais já venham capacitados ao cargo que vão assumir, entretanto considera-se importante haver um planejamento nesse sentido, pois facilitaria tanto para o profissional que está assumindo um cargo novo quanto para a equipe que o recebe.

Essa questão fica clara observando o relato de um dos entrevistados:

"[...] eu estou a pouco tempo aqui e a gente cai meio que de paraquedas, sem entender muito, então você vai em busca do que é mais necessário naquele momento $[\ldots] "$

Essa perspectiva corrobora com a afirmação de Alves et al. ${ }^{60}$ que alertaram para a alocação de profissionais, de diferentes categorias, sem preparo prévio para realizar as tarefas exigidas para o cargo, contando apenas com o conhecimento adquirido na graduação. Os autores afirmaram que para que se alcance um melhor processo de trabalho é necessário desenvolver atributos individuais que extrapolam os conhecimentos adquiridos em programas formais de capacitação, necessitando de capacitação específica e conhecimentos complementares, o que nem sempre acontece, repercutindo negativamente no processo de trabalho do setor ${ }^{60}$.

Miyamoto ${ }^{61}$ é enfático ao citar que muitas categorias profissionais, ingressam no SUS por meio de contratações diretas ou algum tipo de processo seletivo, sem participarem de qualquer tipo de formação ou treinamento específico para seu exercício profissional. Muitos desses não têm formação específica ou possuem uma formação fragmentada e distante do perfil profissional adequado para a maioria dos postos de trabalho na saúde pública. $O$ autor considera ser importante o resgate dos princípios doutrinários e operacionais do SUS e o conhecimento mais aprofundado desse universo, a fim de refletir sobre as práticas que, efetivamente, mudassem a realidade de saúde da população ${ }^{61}$. 


\subsection{REPRESENTAÇÕES DA EDUCAÇÃO PERMANENTE EM SAÚDE PARA O PÚBLICO ALVO}

Esse tema levou em consideração as narrativas dos coordenadores dos distritos de saúde, dos profissionais que atuam no Núcleo de Apoio à Saúde da Família e na Estratégia Saúde da Família.

Com o objetivo de tornar mais elucidativo o material, os dados foram agrupados em duas categorias distintas: a dos apoiadores, incluindo os coordenadores de distrito e os profissionais do NASF e a dos trabalhadores da ESF composta por dois médicos, dois enfermeiros e dois dentistas distribuídos equitativamente entre os três distritos.

O quadro 5.1, apresenta uma síntese das percepções dos apoiadores e profissionais da ESF acerca da EPS, de acordo com o roteiro de questões (Apêndices D e E). 

Quadro 5.1 - Percepções dos apoiadores e profissionais da Estratégia Saúde da Família sobre a Educação Permanente em Saúde, Registro, 2018

\begin{tabular}{|c|c|c|}
\hline Categorias & Apoiadores & Profissionais da ESF \\
\hline $\begin{array}{l}\text { Conhecimento } \\
\text { da PNEP }\end{array}$ & $\begin{array}{l}\text { Todos os coordenadores de distrito } \\
\text { relataram conhecer a PNEP; dos } \\
\text { entrevistados do NASF, nenhum } \\
\text { deles conhecia a política. }\end{array}$ & $\begin{array}{l}\text { Todos citaram não conhecer, nunca } \\
\text { terem lido a portaria, apenas um } \\
\text { citou já ter ouvido falar dela. }\end{array}$ \\
\hline $\begin{array}{l}\text { Participação } \\
\text { na elaboração } \\
\text { das ações de } \\
\text { EPS }\end{array}$ & $\begin{array}{l}\text { As ações de EPS são construídas } \\
\text { conjuntamente envolvendo o } \\
\text { responsável pela EPS, os } \\
\text { coordenadores de distrito e das } \\
\text { categorias profissionais e os } \\
\text { profissionais NASF, de acordo com } \\
\text { avaliação do processo de trabalho e } \\
\text { as necessidades identificadas nas } \\
\text { unidades de saúde, utilizando os } \\
\text { recursos que o município já tenha } \\
\text { disponível. Ainda se leva em } \\
\text { consideração as solicitações dos } \\
\text { profissionais das unidades de } \\
\text { saúde, que trazem as suas } \\
\text { demandas, considerando que } \\
\text { algumas iniciativas partem da } \\
\text { gestão, mas a maioria surge dos } \\
\text { profissionais. Considera-se ainda } \\
\text { que seja uma elaboração } \\
\text { interdisciplinar, uma vez que } \\
\text { envolve várias categorias de } \\
\text { profissionais e Intersetorial visto } \\
\text { que se buscam parcerias com } \\
\text { outras secretarias, ou setores. }\end{array}$ & $\begin{array}{l}\text { A maioria dos profissionais citaram } \\
\text { não existir uma organização muito } \\
\text { compartilhada e que nunca foram } \\
\text { questionados sobre a necessidade } \\
\text { e o interesse em EPS no município } \\
\text { e que nem sempre são } \\
\text { consideradas a realidade e as } \\
\text { expectativas locais e da equipe } \\
\text { durante a sua formulação. } \\
\text { Consideram que a organização é } \\
\text { realizada pela gestão e os } \\
\text { profissionais sâa apenas } \\
\text { convidados a participar das } \\
\text { atividades e os temas já vêm } \\
\text { definidos de cima para baixo. Os } \\
\text { que citaram terem sido consultados } \\
\text { relataram ter sido algo mais pontual, } \\
\text { mas que nem sempre acontece e } \\
\text { que talvez tenha uma participação } \\
\text { maior dos coordenadores. }\end{array}$ \\
\hline $\begin{array}{l}\text { Pertinência em } \\
\text { considerar a } \\
\text { realidade, a } \\
\text { necessidade e } \\
\text { as } \\
\text { expectativas } \\
\text { locais e da } \\
\text { equipe na } \\
\text { elaboração da } \\
\text { EPS }\end{array}$ & Todos concordaram ser importante. & $\begin{array}{l}\text { Todos consideram ser importante a } \\
\text { sua participação durante a } \\
\text { elaboração das ações junto de } \\
\text { quem vai organizar, uma vez que } \\
\text { nem sempre a gestão conhece } \\
\text { verdadeiramente a realidade de } \\
\text { cada unidade, pois eles não estão lá } \\
\text { no dia a dia com os profissionais, e } \\
\text { a realidade de uma unidade não é a } \\
\text { mesma da outra. Desse modo cada } \\
\text { unidade deve ser ouvida e o } \\
\text { planejamento deve ser realizado a } \\
\text { partir do que está acontecendo na } \\
\text { área de abrangência em maior } \\
\text { prevalência naquele momento, de } \\
\text { acordo com o que realmente seja } \\
\text { necessário e que irá acrescentar no } \\
\text { processo de trabalho diário e não se } \\
\text { basear apenas por dados } \\
\text { estatísticos, epidemiológicos e } \\
\text { relatos. }\end{array}$ \\
\hline
\end{tabular}




\begin{tabular}{|c|c|c|}
\hline $\begin{array}{l}\text { Temas } \\
\text { considerados } \\
\text { importantes } \\
\text { para serem } \\
\text { trabalhados na } \\
\text { EPS }\end{array}$ & $\begin{array}{l}\text { Processo de trabalho, organização } \\
\text { das unidades, protocolos, saúde } \\
\text { mental dos pacientes e do } \\
\text { trabalhador, drogadição, questões } \\
\text { sociais, questões identificadas no } \\
\text { território e que refletem na questão } \\
\text { de saúde e no processo de } \\
\text { trabalho. }\end{array}$ & $\begin{array}{l}\text { Saúde mental dos pacientes e } \\
\text { trabalhadores do SUS, processo de } \\
\text { trabalho e organização das } \\
\text { unidades, acolhimento, questões } \\
\text { sociais e de vulnerabilidade, } \\
\text { biossegurança, diabetes, } \\
\text { hipertensão, doenças crônicas, } \\
\text { técnicas práticas e protocolos } \\
\text { referentes a cada formação. }\end{array}$ \\
\hline $\begin{array}{l}\text { Viabilidade } \\
\text { para a } \\
\text { realização de } \\
\text { atividades de } \\
\text { EPS no } \\
\text { município: }\end{array}$ & $\begin{array}{l}\text { Acreditam que teriam apoio da } \\
\text { gestão para a realização de algum } \\
\text { curso, com a dispensa no horário de } \\
\text { trabalho ou flexibilidade de } \\
\text { reposição do horário em outro dia, e } \\
\text { às vezes com recursos para arcar } \\
\text { com os custos de eventuais cursos } \\
\text { fora. } \\
\text { Como dificuldades, os profissionais } \\
\text { apontam a grande demanda de } \\
\text { trabalho, que impossibilita muitas } \\
\text { vezes o profissional se ausentar no } \\
\text { trabalho, e o município não ter } \\
\text { muitas opções de cursos. }\end{array}$ & $\begin{array}{l}\text { Os profissionais relataram nem } \\
\text { sempre ter o apoio da gestão para a } \\
\text { realização de cursos dentro do } \\
\text { horário de trabalho. Como fatores } \\
\text { que facilitariam a realização de } \\
\text { alguma ação de EPS, os } \\
\text { profissionais citaram } \\
\text { principalmente: ter a dispensa no } \\
\text { horário de trabalho; o apoio da } \\
\text { gestão; a disponibilidade de cursos } \\
\text { na modalidade a distância ou que o } \\
\text { município oferecesse no local e a } \\
\text { vontade do profissional. Entre os } \\
\text { fatores que dificultam, a distância foi } \\
\text { a principal queixa, outros fatores } \\
\text { citados foram a grande demanda da } \\
\text { agenda que inviabiliza a ausência } \\
\text { do profissional na unidade, a falta } \\
\text { de recursos humanos, e a falta de } \\
\text { liberação por parte dos } \\
\text { coordenadores. }\end{array}$ \\
\hline $\begin{array}{l}\text { Sugestões de } \\
\text { melhoria para } \\
\text { o processo de } \\
\text { EPS no } \\
\text { município }\end{array}$ & $\begin{array}{l}\text { Organizar melhor o processo de } \\
\text { elaboração, execução, } \\
\text { monitoramento e avaliação das } \\
\text { ações executadas, possibilitando } \\
\text { melhorar o planejamento da forma } \\
\text { como vão trabalhar com cada } \\
\text { equipe para que a EPS ocorra de } \\
\text { uma melhor forma e para que ela } \\
\text { traga frutos. Organização de um } \\
\text { plano de EPS municipal. }\end{array}$ & $\begin{array}{l}\text { Fortalecer mais a EPS no município, } \\
\text { uma vez que hoje conta-se apenas } \\
\text { com uma profissional a frente da } \\
\text { organização, considerando-se } \\
\text { interessante ter mais profissionais } \\
\text { auxiliando e quem sabe formar uma } \\
\text { comissão de EPS sendo possível } \\
\text { assim capacitar melhor os } \\
\text { profissionais que estão na linha de } \\
\text { frente com os usuários. }\end{array}$ \\
\hline
\end{tabular}


Em referência às dificuldades para a realização de atividades de EPS nos municípios, Carotta et al. ${ }^{58}$, também apontou, a rotina diária de trabalho intensa, que dificulta a agenda de encontros da equipe e a possibilidade de aprofundar as reflexões sobre o processo de trabalho, e a desmotivação de alguns trabalhadores. Em contrapartida o documento sobre "Os Princípios e Diretrizes para a Gestão do Trabalho no SUS NOB/RH-SUS" (2005), cita que os gestores das três esferas do SUS devem definir normas, padrões, protocolos e rotinas para a liberação do trabalhador para participar de eventos de capacitação e aperfeiçoamento profissional ${ }^{14}$.

A Portaria $n^{\circ} 1.996$ GM (2007), traz em seu documento a seguinte definição de EPS:

A Educação Permanente é aprendizagem no trabalho, onde o aprender e o ensinar se incorporam ao cotidiano das organizações e ao trabalho. A educação permanente se baseia na aprendizagem significativa e na possibilidade de transformar as práticas profissionais. A educação permanente pode ser entendida como aprendizagemtrabalho, ou seja, ela acontece no cotidiano das pessoas e das organizações. Ela é feita a partir dos problemas enfrentados na realidade e leva em consideração os conhecimentos e as experiências que as pessoas já têm $1^{8}$.

A partir dessa definição buscou-se conhecer dos profissionais o que eles entendiam sobre EPS. Na percepção dos apoiadores ela é uma ferramenta que auxilia no processo de trabalho, propicia momentos de discussão dos problemas levantados, trabalha através do estudo de caso as problemáticas surgidas dentro do próprio trabalho, reformula e reconstrói o próprio ambiente de trabalho, e a partir da EPS surge a necessidade de Educação Continuada.

Os apoiadores relataram que a proposta de EPS é desenvolvida no município, mas que ainda não é uniforme em todas as unidades, visto que algumas equipes já estão acompanhando e se interessando por esse processo, mas outras ainda rejeitam essa metodologia por não entenderem, não conhecerem, e confundirem os termos Educação Permanente e Educação Continuada. Talvez por ainda estarem ligados ao conceito tradicional de educação, seguindo a lógica vertical e programática, relacionando a EPS com cursos e aulas expositivas fornecidas, não conseguindo trazer esse conceito para o dia a dia, deixando de perceber que eles mesmos muitas vezes realizam ações de EPS com sua equipe e comunidade. Caberia aos apoiadores muitas vezes resgatar a diferença de um conceito e outro.

Já para os atuantes na ESF é possível perceber nas falas deles que os entrevistados, ao se reportarem ao mesmo assunto "Educação Permanente", 
abordaram diferentes significados, nem sempre de acordo com o que traz a portaria. Alguns confundiram os termos "Educação Permanente em Saúde" com "Educação Continuada", como é possível observar em alguns dos relatos:

"[...] além de ser uma situação teórica de novos assuntos, ou de novas tecnologias, ou de conhecimentos, também essas experiências que são trocadas, que vão fazendo um norte mais adequado, é um enriquecimento teórico, prático e pessoal [...]" "[...] eu confundo um pouco a Educação Permanente com a Continuada, permanente eu acho que é a do nosso dia a dia, né? É o que a gente precisa para estar se atualizando, para estar desenvolvendo o trabalho, o serviço[...]"

"Educação Permanente eu acredito que seja uma educação continuada, é uma orientação, um apoio educacional ao profissional de saúde".

Essa realidade não é muito diferente daquele identificada no PEEPS do estado de São Paulo (2019). Dos municípios estudados, alguns setores confundem os processos de EPS com os de Educação Continuada e, alguns, sequer conseguem expressar seu entendimento, a não ser, afirmar tratar-se de uma atividade muito importante ${ }^{50}$.

Considera-se relevante destacar que o conhecimento, por parte dos profissionais, sobre o conceito de Educação Permanente e suas práticas educativas pode ser considerado um facilitador para a institucionalidade da PNEPS, uma vez que pode motivar os profissionais a participar desses processos formativos e ainda irão auxiliar no planejamento e desenvolvimento das ações de EPS no município.

Essa problemática foi tratada pelos apoiadores, que acreditavam que algumas ações, consideradas Educação Permanente e que acontecem nas unidades no dia a dia, principalmente no horário semanal reservado para a reunião de equipes, não são identificadas, compreendidas e nomeadas como EPS, quer por desconhecimento, por alguns dos profissionais não se enxergam dentro desse processo e estarem ainda ligados ao modelo tradicional de ensino, ou por confundirem Educação Permanente e Educação Continuada. 
Com relação às concepções de EPS, as informações obtidas junto a diversos setores da Secretaria de Estado da Saúde de São Paulo (SES-SP) reforçam a ideia de que qualquer modalidade educativa voltada aos trabalhadores vem, muitas vezes, sendo considerada como de Educação Permanente, fragilizando a proposta ${ }^{50}$.

Importante citar que no estado de São Paulo existe um leque muito grande de atividades educativas que são inseridas como EPS, incluindo desde rodas de conversas para troca de opiniões sem reflexo nas atividades laborais, até cursos de especialização que, por usarem metodologias ativas e participativas acabam sendo consideradas EPS, sendo importante o entendimento dos colaboradores sobre 0 conceito e as práticas de EPS ${ }^{50}$.

Na percepção dos apoiadores as reuniões de equipe semanais e as mensais entre classes de profissionais (médicos, enfermeiros, dentistas e seus respectivos coordenadores), que pode contar com a participação dos coordenadores de distrito, dos profissionais do NASF e, quando solicitado, do responsável pela EPS, são importantes espaços para a EPS através do levantamento das necessidades, problemas e nós críticos.

Eles ainda enfatizam que a experiência de cada um contribui para o aumento do conhecimento, e que toda vez que a equipe se reúne e constrói algo em conjunto faz muito mais sentido para todos do que apresentar algo pronto e dizer que aquilo deverá ser seguido, pois muitas vezes não será, uma vez que não condiz com a realidade de cada unidade.

Essa percepção é reforçada pelos profissionais das Unidades de Saúde que trouxeram que se deve trabalhar as singularidades, dificuldades e interesse das equipes, e que as propostas sejam tangíveis e que depois as unidades tenham o suporte e governabilidade para colocá-las em prática no dia a dia, de acordo com o contexto de cada um.

Peduzzi et al. ${ }^{62}$, afirmam que as atividades educativas com origem na própria UBS e que ali são realizadas têm maior possibilidade de contar com a participação dos trabalhadores, e ações como reuniões entre trabalhadores constituem uma ferramenta importante aplicadas por meio da comunicação e da interação entre os profissionais através da construção de espaços de troca, negociação e busca de consensos.

Mesmo não sendo nomeada de tal forma, foi possível notar pelas entrevistas com os profissionais da ESF, que ocorre um movimento de EPS nas unidades, ainda 
que pequeno realizado por eles, uma vez que esses elaboram ações dentro da sua área de formação, tanto para sua equipe, quanto para os pacientes e/ou comunidade dentro do seu território de acordo com sua governabilidade. Eles mesmos consideraram que poderiam fazer mais, mas o grande empecilho era a falta de tempo.

Com relação ao processo de Educação Permanente como uma estratégia metodológica de ensino, os apoiadores salientaram que a EPS reformula o processo de ensino aprendizagem, uma vez que substitui um modelo de ensino tradicional hierarquizado de cima para baixo, apresentado na forma de aula e planejado por um professor e/ou palestrante para os envolvidos de acordo com a noção que ele tinha sobre o que os profissionais precisavam. Entendem-na como um conjunto de atividades cujo planejamento seja feito em parceria e de acordo com as necessidades dos profissionais, dos problemas que surgem no dia a dia do próprio ambiente de trabalho, com o objetivo de repensar o processo de trabalho.

Essa percepção corrobora com o documento PEEPS do estado de São Paulo (2019), que traz que a EPS busca se constituir em uma nova estratégia educativa a fim de superar a fórmula pedagógica que prevalece nas capacitações tradicionais. Isso porque se comprovou que as capacitações tradicionais, de modo geral, não propiciam os resultados esperados e seus conteúdos não produzem impacto nas práticas do cotidiano dos serviços, na medida em que são organizadas apenas com base na transmissão de conhecimentos e descontextualizadas da realidade, vivências e saberes prévios dos sujeitos envolvidos na ação educativa ${ }^{50}$.

Esse entendimento vem de encontro também com o artigo "EPS em movimento", de 2014, que traz em seu texto que estamos acostumados a entender o processo de educação como um repasse de conhecimento, no qual alguém que teoricamente saiba mais transfere o conhecimento para um grupo, entretanto na EPS, o trabalhador é um sujeito ativo, ou seja, ele vai participar do processo de construção desse conhecimento, sendo também autor e produtor do conhecimento, não sendo apenas aquele conhecimento produzido na universidade que é valorizado, mas sim toda a experiência adquirida no dia-a-dia do trabalho ${ }^{56}$.

Cabe aqui destacar que a lógica da Educação Permanente é descentralizadora, ascendente e transdisciplinar, assim, os processos educativos deixam a lógica de sala de aula e abre-se espaço para a dinâmica participativa ${ }^{6}$.

Um ponto importante a frisar é que temos que ter cuidado na forma de conduzir as metodologias de ensino escolhidas, para que realmente faça sentido para os 
profissionais envolvidos e que eles realmente adquiram o conhecimento proposto naquela atividade.

Foi percebida na fala de um profissional a dificuldade de compreensão das novas metodologias, como a roda de conversa, e até mesmo dos cursos EaD; assim, é importante se pensar em metodologias passíveis de serem compreendidas e bem aproveitadas por todos.

Ainda foi citado que se fosse aberto um espaço dentro do horário de trabalho para um momento de estudo facilitaria a adesão aos cursos oferecidos pelo MS de EPS na modalidade EaD.

Essas dificuldades no entendimento e uso da ferramenta EaD, e a falta de tempo para a realização dos cursos, é destacado no estudo de Oliveira ${ }^{35}$, segundo o autor existem certos desafios para o desenvolvimento dos cursos, entre eles destacam-se, a dificuldade de acesso às tecnologias da comunicação e informação por parte de alguns profissionais de saúde, dificuldade em utilizar as ferramentas, escassez de tempo para desenvolver as atividades do curso em vista do duplo emprego, dificuldade de comunicação com os tutores por morar em locais muito distantes, além dos problemas pessoais e/ou familiares que enfrentam ${ }^{35}$.

Vale aqui destacar que no Estado de São Paulo existe uma importante infraestrutura de suporte a EaD em Saúde, incluindo estruturas da própria SES-SP, das Instituições de Ensino Superior e Técnico e outras estruturas existentes nas instituições de saúde ${ }^{50}$.

Os profissionais da ESF mostraram-se motivados para buscar e realizar novas formações e capacitações, e apontam como fatores o interesse próprio; a curiosidade; a busca por mais conhecimento e aprimoramento, quer seja por conhecer novas técnicas ou por trocar experiências; o gosto pelo estudo e a busca de conhecimento de acordo com as necessidades para que possa ser aplicado na prática diária do trabalho.

Eles ainda citaram que voltam dos cursos mais motivados, querendo colocar em prática todo aquele aprendizado, e isso se reflete no processo de trabalho, uma vez que se consegue trabalhar de uma forma diferente, olhar o paciente de outra forma, de uma maneira mais abrangente, com segurança e, consequentemente melhora a qualidade do serviço prestado. 
Ao mesmo tempo eles relatam que nem sempre é possível aplicar na prática o aprendizado adquirido, embora sejam relevantes, principalmente quando envolvem equipes, o que pode gerar frustações.

Esse alerta é sustentado por $\mathrm{Luz}^{9}$, que discorre em seu trabalho que no dia a dia da equipe, nem todo o conhecimento adquirido é possível ser colocado em prática e compartilhado com os demais membros da equipe, uma vez que, muitas vezes o profissional adquire conhecimentos que não condizem com a realidade do trabalho, ou não tem a colaboração dos membros da equipe para que a proposta seja realizada, deixando assim o profissional muitas vezes frustrado e as ideias arquivadas, tendo essa dificuldade ser melhor trabalhada para ser sanada dentro dos processos de EPS.

Percebeu-se certa ambiguidade no processo de implantação da ESP no município a partir das falas dos sujeitos, mas também disponibilidade entre todos os envolvidos para que ela seja fortalecida, posto que todos concordaram que ela contribui para a qualificação do trabalho.

\subsection{RELATÓRIO}

Diante das observações e registros desse estudo e de todas as mudanças e avanços que ocorrem constantemente no sistema de saúde, é possível afirmar que os profissionais da saúde necessitam de frequente atualização. A Educação Permanente em Saúde se coloca como uma relevante ferramenta que pode auxiliar na transformação das práticas profissionais, uma vez que as ações são realizadas dentro da realidade de cada equipe.

Essa relevância se faz mister principalmente pelo fato do município estar localizado em uma região de vários municípios de pequeno porte, não tendo muita estrutura de universidades, tendo os interessados que se deslocarem para os grandes centros, como Curitiba, no estado do Paraná ou São Paulo, capital, ambas a mais de $200 \mathrm{~km}$ de distância, o que dificulta que os profissionais se mantenham atualizados; assim o fortalecimento da EPS no município pode ser um facilitador.

Ainda é importante destacar que nos últimos três anos o município passou por uma grande substituição de recursos humanos, que antes eram contratados e hoje são concursados. 
Ocorreu também nessa mesma época a ampliação das unidades de ESF, e a EPS pôde ser considerada um recurso facilitador desse processo para capacitar os novos colaboradores.

Pode-se dizer que as contratações já estão estabilizadas e as equipes praticamente completas, uma vez que todas as ESF contam com médicos, enfermeiros e técnicos de enfermagem. Algumas unidades ainda estão apenas com déficit de Agentes Comunitários de Saúde e Auxiliares Administrativos. A equipe de Saúde Bucal, também não está completa, uma vez que não são todas unidades de ESF que conta com uma.

O município contava com uma cobertura da população de aproximadamente $100 \%$.

Foi possível perceber que a Educação Permanente em Saúde está presente no cotidiano dos trabalhadores e percebeu-se intencionalidade em exercê-la, desde que possa ser reconhecida por todos como tal e estimulada pelos gestores.

Assim, para o fortalecimento da Educação Permanente em Saúde no município de Registro- SP os entrevistados sugeriram algumas propostas como: a criação de um núcleo de EPS, uma vez que o município contava na época da pesquisa com apenas um responsável pela prática e pensar na capacitação dos colaboradores do núcleo para que esses possam ser facilitadores da EPS no município, bem como disseminar a Política e o conceito de Educação Permanente em Saúde nas unidades de saúde para que os envolvidos se enxerguem dentro desee contexto e colaborem com a elaboração das ações.

Realizar o planejamento de um plano municipal de EPS, que atenda as necessidades e expectativas referidas pelas unidades de saúde, o que geraria um documento norteador para as ações e também poderia facilitar a adesão das equipes e profissionais nas ações propostas, uma vez que existe um período semanal reservado (quinta feita à tarde) para que ações como esta ocorram em todas as unidades de ESF, bem como nas reuniões mensais com cada categoria profissional (médicos, enfermeiros, dentistas e respectivos coordenadores). 
Ainda foi levantada a necessidade de criar indicadores de processo e resultados que permitam acompanhar, monitorar e avaliar as ações já realizadas no município e auxiliar na elaboração de ações futuras, possibilitando melhor implementação da PNEPS no município, e que todos os projetos de EPS sejam documentados, para que mesmo em situação de troca da gestão, os projetos permaneçam; e não sejam descontinuados.

Com bases nesses dados, foi elaborado o plano de intervenção (Apêndice F). 


\section{CONCLUSÃO}

A Educação Permanente em Saúde no município é recente e se apresenta em processo de implantação.

Foi possível perceber conhecimento e compatibilidade, por parte do responsável pela EPS e alguns colaboradores, com a legislação vigente, embora ainda não cumprida em sua totalidade.

Todavia o conhecimento da EPS ainda não era de domínio da maioria dos profissionais entrevistados, que carecem de mais discussões conceituais. A formação de um Núcleo de EPS poderia ampliar a rede de profissionais envolvidos com esses processos, aumentando o diálogo e contribuindo para diminuir a distância entre os formuladores das propostas e os beneficiados por elas.

Constatou-se que muito se alcançou, porém, muito ainda há o que ser feito com o objetivo de aproveitar melhor essa ferramenta, principalmente com relação à falta de um plano municipal e de mecanismos de avaliação e monitoramento das ações desenvolvidas, que auxiliariam na elaboração de ações futuras. 



\section{REFERÊNCIAS 1}

1. Carvalho YM, Ceccim RB. Formação e educação em saúde: aprendizados com a saúde coletiva. In: Campos GWS, Minayo MCS, Akerman M, Drumond M, Carvalho YM, organizadores. Tratado de Saúde Coletiva. $2^{\mathrm{a}}$ ed. São Paulo: Hucitec; 2006. p. 149-82.

2. Brasil. Constituição 1988. Constituição da República Federativa do Brasil. Brasília (DF): Senado; 1988.

3. Brasil. Lei n. 8.080 de 19 de setembro de 1990. Dispõe sobre as condições para a promoção, proteção e recuperação da saúde, a organização e o funcionamento dos serviços correspondentes e dá outras providências. Diário Oficial da União, Brasília (1990 set. 19).

4. Cunha IS. Educação permanente em saúde e planejamento estratégico situacional: o caso da Secretaria Estadual de Saúde do Piauí [dissertação]. Rio de Janeiro: Fundação Oswaldo Cruz, Escola Nacional de Saúde Pública Sérgio Arouca; 2009.

5. Ministério da Saúde. Secretaria de Gestão do Trabalho e da Educação na Saúde. Departamento de Gestão da Educação na Saúde. A educação permanente entra na roda: pólos de educação permanente em saúde: conceitos e caminhos a percorrer. Brasília: Ministério da Saúde; 2005. 36 p.

6. Ministério da saúde. Secretaria de Gestão do Trabalho e da Educação na Saúde. Departamento de Gestão da Educação na Saúde. Políticas de formação e de desenvolvimento para o SUS: Caminho para a educação permanente em saúde. Brasília: Ministério da Saúde; 2003. 21 p.

7. Ministério da Saúde. Secretaria de Gestão do Trabalho e da Educação na Saúde. Departamento de Gestão da Educação na Saúde. Política Nacional de Educação Permanente em Saúde: Brasília: Ministério da Saúde; 2009. 65p.

8. Brasil. Ministério da Saúde. Institui a Política Nacional de Educação Permanente em Saúde como estratégia do Sistema Único de Saúde para a formação e o desenvolvimento de trabalhadores para o setor e dá outras providências. Portaria n. 198/GM, 13 fevereiro 2004.

\footnotetext{
${ }^{1}$ De acordo com Estilo Vancouver.
} 
9. Luz FM. Educação permanente em saúde (EPS): uma estratégia que possibilita transformações no processo de trabalho [trabalho de conclusão de curso]. Minas Gerais: Universidade Federal de Minas Gerais; 2010.

10. Vendruscolo C, Ferraz F, Zocche DAA, Schweickardt JC, Sandri JVA, Wendhausen FTB et al. Série Atenção Básica e Educação na Saúde. Frutos dos movimentos de Educação Permanente em Saúde de Santa Catarina: Caminhos e Oportunidades. $1^{\circ}$ ed. Porto Alegre: UNIDA; 2018. 348 p.

11. Vendruscolo C, Ferraz F, Zocche DAA, Schweickardt JC, Sandri JVA, Wendhausen FTB et al. Série Atenção Básica e Educação na Saúde. Educação Permanente em Saúde de Santa Catarina: entre cenários e práticas. $1^{\circ} \mathrm{ed}$. Porto Alegre: UNIDA; 2018. $332 \mathrm{p}$.

12. França T. Análise da Política de Educação Permanente do SUS implementada pelas Secretarias Estaduais de Saúde. Rio de Janeiro: Universidade do Estado do Rio de Janeiro Instituto de Medicina Social; 2016. $341 \mathrm{p}$.

13. Deslandes SF. Concepções em pesquisa social: articulações com o campo da avaliação em serviços de saúde. Cad. Saúde Públ. Rio de Janeiro, 1997 janmar; 13(1):103-7.

14. Ministério da Saúde. Conselho Nacional de Saúde. Princípios e diretrizes para a gestão do trabalho no SUS (NOB/ RH- SUS). $3^{\circ}$ ed. Brasília: Ministério da Saúde; 2005. 98p.

15. Brasil. Ministério da Saúde. Divulga o Pacto pela Saúde 2006- Consolidação do SUS e aprova as Diretrizes Operacionais do Referido Pacto. Portaria $\mathrm{n}$. 399/GM, 22 fevereiro 2006.

16. Brasil. Ministério da Saúde. Aprova a Política Nacional de Atenção Básica, estabelecendo a revisão de diretrizes e normas para a organização da Atenção Básica para o Programa Saúde da Família (PSF) e o Programa Agentes Comunitários de Saúde (PACS). Portaria n. 648/GM, 28 março 2006.

17. Brasil. Ministério da Saúde. Aprova a Política Nacional de Atenção Básica, estabelecendo a revisão de diretrizes e normas para a organização da Atenção Básica, para a Estratégia Saúde da Família (ESF) e o Programa de Agentes Comunitários de Saúde (PACS). Portaria n. 2.488, 21 outubro 2011. 
18. Brasil. Ministério da Saúde. Dispõe sobre as diretrizes para a implementação da Política de Educação Permanente em Saúde. Portaria n. 1.996/GM, 20 agosto 2007.

19. Cardoso MLM, Costa PP, Costa DM, Xavier C, Souza RMP. A Política Nacional de Educação Permanente em Saúde nas Escolas de Saúde Pública: reflexões a partir da prática. Ciênc Saúde Coletiva. 2017; 22(5):1489-1500.

20. Brasil. Ministério da saúde. Aprova a Política Nacional de Atenção Básica, estabelecendo a revisão de diretrizes para a organização da Atenção Básica, no âmbito do Sistema Único de Saúde. Portaria n. 2436, 21 setembro 2017.

21. Brasil. Consolidação das normas sobre as políticas nacionais de saúde do Sistema Único de Saúde. Portaria de Consolidação n. 2, 28 setembro 2017.

22. Brasil. Consolidação das normas sobre o financiamento e a transferência dos recursos federais para as ações e os serviços de saúde do Sistema Único de Saúde. Portaria de Consolidação n. 6, 28 setembro 2017.

23. Brasil. Ministério da saúde. Dispõe sobre o Programa para o Fortalecimento das Práticas de Educação Permanente em Saúde no Sistema Único de Saúde - PRO EPS-SUS. Portaria n. 3.194, 28 novembro 2017.

24. Brasil. Ministério da saúde. Divulga lista dos entes federados habilitados ao recebimento do incentivo financeiro de que trata a Portaria no 3.194/GMS/MS de 27 de novembro de 2017. Portaria n. 3.342, 7 dezembro 2017.

25. Cezar DM, Costa MR, Magalhães RC. Educação a Distância como uma estratégia para a Educação Permanente em Saúde? Rev Educação Distância (Em Rede). 2017 Jun; 4 (1):107-15.

26. Santos CM, Tenório FPS, Kich FD. Educação Permanente em Saúde no Estado de Sergipe Saberes e tecnologias para implantação de uma política. $1^{\circ}$. ed. Aracaju: Fundação Estadual de Saúde- FUNESA; 2011.

27. Junior JPB, Moreira DC. Educação Permanente e apoio matricial: Formação, vivencias e práticas dos profissionais dos núcleos de apoio à Saúde da Família e das equipes apoiadas. Cad. Saúde Pública. 2017; 33 (9):108-16. 
28. Merhy EE, Feuerwerker LCM, Ceccim RB. Educación Permanente en Salud: una Estrategia para Intervenir en la Micropolítica del Trabajo en Salud.

SALUD COLECTIVA. 2006 Mayo - Agosto; 2(2): 147-60.

29. Ceccim RB. Educação Permanente em Saúde: descentralização e disseminação de capacidade pedagógica na saúde. Ciên Saúde Coletiva. 2005; 10 (4): 975-86.

30. Freire P. Pedagogia da Autonomia. Saberes Necessários à prática Educativa. 25a ed. São Paulo: Editora Paz e Terra S/A; 2002. 54 p.

31. Dolny LL, Lacerda JT, Nilson LG, Monteiro ER, Maeyama MA, Calvo MCM. Educação Permanente: Origens e Caminhos no Sistema Único de Saúde. In: Vendruscolo C, Vendruscolo C, et al. Série Atenção Básica e Educação na Saúde. Frutos dos movimentos de Educação Permanente em Saúde de Santa Catarina: Caminhos e Oportunidades. $1^{\circ}$ ed. Porto Alegre: UNIDA; 2018. P. 24-58.

32. Brasil. Ministério da saúde. Institui diretrizes para implementação da Política de Educação Permanente em Saúde, no âmbito do Ministério da Saúde (MS). Portaria n. 278, de 27 de fevereiro de 2014.

33. Barreto V. Paulo Freire para educadores. 25a ed. São Paulo: Arte e Ciência; 1998. $136 \mathrm{p}$.

34. Batista KBC, Gonçalves OSJ. Formação dos profissionais de saúde para o SUS: Significado e Cuidado. Saúde Soc. 2011; 20(4): 884-99.

35. Oliveira MAN. Educação à Distância como estratégia para a educação permanente em saúde: possibilidades e desafios. Rev Bras Enfermagem. 2007 set-out; 60(5): 585- 89.

36. Brasil. Lei n. 9.394, de 20 de dezembro de 1996. Estabelece as diretrizes e bases da educação nacional. Diário Oficial da União, Brasília (1996 dez. 20).

37. Brasil. Decreto n. 9.057, de 25 de maio de 2017. Regulamenta o art. 80 da Lei no 9.394, de 20 de dezembro de 1996, que estabelece as diretrizes e bases da educação nacional. Diário Oficial da União, Brasília (2017 maio 25). 
38. Brasil. Decreto n. 5.800, de 8 de junho de 2006. Dispõe sobre o Sistema Universidade Aberta do Brasil - UAB. BRASIL. Diário Oficial da União, Brasília (2006 jun. 8).

39. Brasil. Decreto n. 7.385, de 8 de dezembro de 2010. Institui o Sistema Universidade Aberta do Sistema Único de Saúde - UNA -SUS, e dá outras providências. Diário Oficial da União, Brasília (2010 dez 8).

40. Brasil GVS. Análise de um curso de especialização em atenção básica através de narrativas de estudantes do programa mais médicos [dissertação]. Maranhão: Universidade Federal do Maranhão; 2018.

41. Wikipédia: a enciclopédia livre [Internet]. Vale do Ribeira [citado 22 dez. 2018]. Disponível em: https://pt.wikipedia.org/wiki/Vale do Ribeira .

42. IBGE- Instituto Brasileiro de Geografia e Estatística. Estatística por cidade e estado [citado 22 dez. 2018]. Disponível em:

https://www.ibge.gov.br/informacoes-por-cidade-eestado.html?t=destaques\&c=3542602 .

43. Secretaria de Desenvolvimento Social do Estado de São Paulo. Painel Social. $9^{\circ}$ ed. Junho de 2015.

44. Governo do Estado de São Paulo. Secretaria de Estado e Saúde. DRS XIIRegistro [citado 06 set. 2019]. Disponível em: http://www.saude.sp.gov.br/ses/institucional/departamentos-regionais-desaude/drs-xii-registro.

45. Governo do Estado de São Paulo. Secretaria de Estado e Saúde. Regionais de Saúde [citado 06 set. 2019]. Disponível em: http://www.saude.sp.gov.br/ses/institucional/departamentos-regionais-desaude/regionais-de-saude .

46. Trad LAB. Grupos focais: conceitos, procedimentos e reflexões baseadas em experiências com o uso da técnica em pesquisas de saúde. Physis Rev Saúde Coletiva. 2009; 19 (3 ): 777-96.

47. Bardin L. Análise de conteúdo. São Paulo: Edições 70, 2011. 
48. Silva AH, Fossá MIT. Análise de Conteúdo: Exemplo de aplicação da técnica para análise de dados qualitativos. Qualit@s Rev Eletrônica. 2015: 17(1).

49. Franco MLPB. Análise de Conteúdo. $5^{\circ}$ ed. Campinas: Editora Autores Associados; 2018. 96 p.

50. Ministério da Saúde. PRO EPS-SUS. Plano Estadual de Educação Permanente em Saúde do Estado de São Paulo 2020-2023. São Paulo. 66p.

51. Merhy EL. Educação Permanente em Movimento - uma política de reconhecimento e cooperação, ativando os encontros do cotidiano no mundo do trabalhador em saúde, questões para os gestores, trabalhadores e quem mais quiser se ver nisso. Saúdes em Redes. 2015: 1(1): 07-14.

52. Brasil. Ministério da Saúde. Institui, no âmbito do Sistema Único de Saúde, o Programa Nacional de Melhoria do Acesso e da Qualidade da Atenção Básica (PMAQ-AB) e o Incentivo Financeiro do PMAQ-AB, denominado Componente de Qualidade do Piso de Atenção Básica Variável - PAB Variável. Portaria n. 1.654 , de 19 de julho de 2011.

53. Brasil. Ministério da Saúde. Dispõe sobre o Programa Nacional de Melhoria do Acesso e da Qualidade da Atenção Básica (PMAQ-AB). Portaria n. 1.645, de 2 de outubro de 2015.

54. Brasil. Ministério da Saúde. Homologa a adesão dos Municípios e das respectivas equipes de Atenção Básica ao Programa Nacional de Melhoria do Acesso e da Qualidade da Atenção Básica (PMAQ-AB). Portaria n. 2.812, de 29 de novembro de 2011.

55. Bezerra MM, Medeiro KR. Limites do Programa de Melhoria do Acesso e da Qualidade da Atenção Básica (PMAQ-AB): em foco, a gestão do trabalho e a educação na saúde. Saúde Debate. 2018: 42 (2): 188-202.

56. EPS EM MOVIMENTO. Educação e trabalho em saúde: a importância do saber da experiência. 2014 [citado 03 jan. 2019]. Disponível em: http://eps.otics.org/material/entrada-textos/educacao-e-trabalho-em-saude-aimportancia-do-saber-da-experiencia . 
57. Brasil. Lei n. 12.871, de 22 de outubro de 2013. Institui o Programa Mais Médicos, altera as Leis no 8.745, de 9 de dezembro de 1993, e oㅡ 6.932, de 7 de julho de 1981, e dá outras providências. Diário Oficial da União, Brasília (2013 out. 22).

58. Carotta F, Kawamura D, Salazar J. Educação Permanente em Saúde: uma estratégia de gestão para pensar, refletir e construir práticas educativas e processos de trabalhos. Saúde e Sociedade. 2009;18(1): 48-51.

59. Consaúde. Consórcio Intermunicipal de Saúde do Vale do Ribeira. Centro de Formação de Recursos Humanos [citado 25 dez. 2018]. Disponível em: http://www.consaude.org.br/ceforh/.

60. Alves M, Penna CMM, Brito MJM. Perfil dos Gerentes de Unidades Básicas de Saúde. Rev Bras Enferm, Brasília (DF) 2004 jul-ago;57(4):441-6.

61. Miamoto GA. Núcleo de Educação Permanente em região de municípios de pequeno/médio porte: desafios e potencialidades [dissertação]. São Paulo: Programa de Mestrado Profissional em Saúde Coletiva da Coordenadoria de Recursos Humanos da Secretaria de Estado da Saúde de São Paulo, 2014.

62. Peduzzi M, Guerra DAD, Braga CP, Lucena FS, Silva JAM. Atividades educativas de trabalhadores na atenção primária: concepções de educação permanente e de educação continuada em saúde presentes no cotidiano de Unidades Básicas de Saúde em São Paulo. Interface. Interface Comunicação Saúde Educação. 2009 jul/set; 13 (30): 121-34. 



\section{APÊNDICE A - Termo de Consentimento Livre e Esclarecido para as entrevistas individuais}

\section{A experiência da Educação Permanente em Saúde no município de Registro, São Paulo}

Você está sendo convidado (a) a participar de forma voluntária desse estudo, acima citado, sob a responsabilidade da pesquisadora Daiane Mayara Alves, sob orientação da Profa. Dra. Simone Rennó Junqueira, do curso de Mestrado Profissional Interunidades Formação Interdisciplinar em Saúde, pertencente à Faculdade de Odontologia da Universidade de São Paulo (USP).

A finalidade dessa pesquisa é conhecer a experiência do processo de planejamento, organização e execução das ações de Educação Permanente em Saúde, desenvolvidas no município de Registro, Estado de São Paulo.

Participarão dessa pesquisa os responsáveis pela Educação Permanente em Saúde no município, os coordenadores dos distritos de saúde e também profissionais atuantes na Estratégia Saúde da Família (ESF) e no Núcleo de Apoio à Saúde da Família (NASF) da Prefeitura Municipal de Registro/SP, previamente selecionados, de maneira intencional, em função do tempo que atuam nos respectivos serviços. O responsável pela Educação Permanente e os profissionais atuantes na ESF e no NASF serão submetidos a uma entrevista individual, direcionada por um questionário previamente elaborado que será aplicado pelo próprio pesquisador, onde todos os profissionais poderão discorrer sobre o tema da pesquisa e expor suas opiniões, com tempo estimado de 60 minutos. As entrevistas serão gravadas para que se possa aumentar a capacidade de registro das informações e para que possam ser posteriormente analisadas. Ao participar dessa pesquisa você irá contribuir com informações relevantes que poderão identificar pontos facilitadores e limitantes do processo de elaboração e execução das ações de Educação Permanente em Saúde no município.

Diante das características da pesquisa, a possibilidade de risco ao participante é mínima, podendo ocorrer pontualmente uma perturbação nas atividades de trabalho, a exposição de ideias ou ao constrangimento, porém o sigilo e anonimato serão garantidos, mediante o Termo de Consentimento Livre e Esclarecido, mesmo após a finalização e publicação dos resultados.

Você tem a liberdade de se recusar a participar da pesquisa a qualquer momento sem que ocorra qualquer prejuízo ou penalidade. Sua identidade será preservada(o), mesmo após a finalização e publicação da pesquisa.

Os procedimentos utilizados nessa pesquisa obedecem aos Critérios da Ética na Pesquisa com Seres Humanos, conforme resolução 466/12 do Conselho Nacional de Saúde - Brasília - DF.

Ao concordar em participar da pesquisa você não receberá nenhum pagamento e não terá nenhum gasto porque a entrevista individual será realizada na própria unidade de saúde e/ou secretaria de saúde onde ficam alocados os profissionais selecionados, de acordo com a data e horário previamente combinado. Você também não terá nenhum benefício direto, mas sua contribuição poderá acrescentar elementos importantes à literatura, onde o pesquisador se compromete a divulgar os resultados. Os dados obtidos na pesquisa serão utilizados somente para este estudo e as gravações, após analise, serão destruídas. Esclarecido.

Após concordar em participar da pesquisa você receberá uma cópia desse Termo de Consentimento Livre e

Quando necessário e a qualquer momento da pesquisa, você poderá solicitar esclarecimento ao pesquisador responsável através do telefone (11) 9.88425910 ou e-mail day.malves@hotmail.com. Quanto à ética da pesquisa você poderá entrar em contato com o Comitê de Ética em Pesquisa em Seres Humanos da Faculdade de Odontologia, situado na Av. Prof. Lineu Prestes, 2227, 05508-000 São, Paulo, telefone (11) 3091-7960 ou pelo e-mail cepfo@usp.br (horário de funcionamento: segunda a sexta-feira, das 8 às $17 \mathrm{~h}$, exceto feriado e recesso universitário). O Comitê é um colegiado interdisciplinar e independente, de relevância pública, de caráter consultivo, deliberativo e educativo, criado para defender os interesses dos participantes da pesquisa em sua integridade e dignidade para contribuir no desenvolvimento da pesquisa dentro de padrões éticos (Resolução CNS no 466 de 2012).

\section{AUTORIZAÇÃO}

Após ler as informações e ter as minhas dúvidas suficientemente esclarecidas pelo pesquisador, concordo em participar de forma voluntária nesse estudo.

Em de de 2018.
Profa. Dra. Simone Rennó Junqueira Orientadora (№ USP 1988460)
Daiane Mayara Alves

Pesquisadora (№ USP 8700162) 



\section{APÊNDICE B - Termo de Consentimento Livre e Esclarecido para o Grupo Focal (Coordenadores de distrito)}

\section{A experiência da Educação Permanente em Saúde no município de Registro, São Paulo}

Você está sendo convidado (a) a participar de forma voluntária desse estudo, acima citado, sob a responsabilidade da pesquisadora Daiane Mayara Alves, sob orientação da Profa. Dra. Simone Rennó Junqueira, do curso de Mestrado Profissional Interunidades Formação Interdisciplinar em Saúde, pertencente à Faculdade de Odontologia da Universidade de São Paulo (USP).

A finalidade dessa pesquisa é conhecer a experiência do processo de planejamento, organização e execução das ações de Educação Permanente em Saúde desenvolvido no município de Registro, Estado de São Paulo.

Participarão dessa pesquisa os responsáveis pela Educação Permanente em Saúde no município, os coordenadores dos distritos de saúde e também profissionais atuantes na Estratégia Saúde da Família (ESF) e no Núcleo de Apoio à Saúde da Família (NASF) da Prefeitura Municipal de Registro/SP, previamente selecionados, de maneira intencional, em função do tempo que atuam nos respectivos serviços.

Os coordenadores de distrito serão submetidos a um grupo focal, direcionado por um roteiro previamente elaborado e que será aplicado pelo próprio pesquisador, onde todos os profissionais poderão discorrer sobre o tema da pesquisa e expor suas opiniões, com tempo estimado de 90 minutos. O grupo focal e as entrevistas serão gravadas para que se possa aumentar a capacidade de registro das informações e para que possam ser posteriormente analisadas. Ao participar dessa pesquisa você irá contribuir com informações relevantes que poderão identificar pontos facilitadores e limitantes do processo de elaboração e execução das ações de Educação Permanente em Saúde no município.

Diante das características da pesquisa, a possibilidade de risco ao participante é mínima, podendo ocorrer pontualmente uma perturbação nas atividades de trabalho, a exposição de ideias ou ao constrangimento, porém o sigilo e anonimato serão garantidos, mediante o Termo de Consentimento Livre e Esclarecido, mesmo após a finalização e publicação dos resultados.

Você tem a liberdade de se recusar a participar da pesquisa a qualquer momento, sem que ocorra qualquer prejuízo ou penalidade. Sua identidade será preservada (o), mesmo após a finalização e publicação da pesquisa.

Os procedimentos utilizados nessa pesquisa obedecem aos Critérios da Ética na Pesquisa com Seres Humanos, conforme resolução 466/12 do Conselho Nacional de Saúde - Brasília - DF.

Ao concordar em participar da pesquisa você não receberá nenhum pagamento e não terá nenhum gasto porque o grupo focal será realizado na data de uma reunião que ocorre semanalmente entre os coordenadores, de acordo com a data e horário previamente combinado. Você também não terá nenhum benefício direto, mas sua contribuição poderá acrescentar elementos importantes à literatura, onde o pesquisador se compromete a divulgar os resultados. Os dados obtidos na pesquisa serão utilizados somente para este estudo e as gravações, após analise, serão destruídas. Esclarecido.

Após concordar em participar da pesquisa você receberá uma cópia desse Termo de Consentimento Livre e

Quando necessário e a qualquer momento da pesquisa você poderá solicitar esclarecimento ao pesquisador responsável através do telefone (11) 9.88425910 ou e-mail day.malves@hotmail.com. Quanto à ética da pesquisa você poderá entrar em contato com o Comitê de Ética em Pesquisa em Seres Humanos da Faculdade de Odontologia, situado na Av. Prof. Lineu Prestes, 2227, 05508-000 São, Paulo, telefone (11) 3091-7960 ou pelo e-mail cepfo@usp.br (horário de funcionamento: segunda a sexta-feira das 8 às $17 \mathrm{~h}$, exceto feriado e recesso universitário). O Comitê é um colegiado interdisciplinar e independente, de relevância pública, de caráter consultivo, deliberativo e educativo, criado para defender os interesses dos participantes da pesquisa em sua integridade e dignidade para contribuir no desenvolvimento da pesquisa dentro de padrões éticos (Resolução CNS no 466 de 2012).

\section{AUTORIZAÇÃO}

Após ler as informações e ter as minhas dúvidas suficientemente esclarecidas pelo pesquisador, concordo em participar de forma voluntária nesse estudo.

Em de de 2018.

Nome do entrevistado CPF/RG

Assinatura do entrevistado

Profa. Dra. Simone Rennó Junqueira

Orientadora (№ USP 1988460)
Daiane Mayara Alves

Pesquisadora (№ USP 8700162) 

APÊNDICE C - Questionário estruturado, direcionado ao responsável pela Educação Eermanente em Saúde no município

\section{Bloco 1: Caracterização da Educação Permanente em Saúde no município}

1) Existe uma Política Municipal de Educação Permanente em Saúde (PMEPS)? Ela está acessível ou já foi apresentada aos profissionais em algum momento?

2) Você sabe relatar como foi o processo de elaboração desta politica? Ela está baseada na Politica Nacional de Educação Permanente em Saúde (PNEPS)?

3) Esta politica contempla as questões da formação e desenvolvimento dos trabalhadores para o SUS? Quais as linhas de ações que estão contempladas na PMEPS?

4) Que estrutura organizacional é responsável pela condução dessa politica no município?

5) Existem Comissões Permanentes de Integração Ensino-Serviço (CIES). O município faz parte de alguma? O que determina essa relação e como ela acontece?

6) Quem participa da formulação e implementação da PMEPS diretamente?

7) Os trabalhadores de saúde participam da elaboração da Educação Permanente em Saúde no município? Se sim, relate quais e como é a sua contribuição.

8) São consideradas a realidade, a necessidade e as expectativas locais para a elaboração de ações Educação Permanente em Saúde? Como isso é feito?

9) São consideradas as necessidades de qualificação profissional (de nível superior e técnico) para a elaboração de ações Educação Permanente em Saúde? E você sabe relatar quais são as principais?

10) Existe alguma estratégia que visa reorientar a formação dos profissionais da saúde de acordo com os princípios e diretrizes no SUS (Hospital, UPA, NASF, ESF)? 11)Existe alguma parceria no desenvolvimento das ações de Educação Permanente com outros municípios e/ou instituições de ensino?

12) $O$ município realiza atividades junto à regional de saúde? Se sim, relate.

13) Existe algum incentivo para os profissionais de saúde participarem dos processos educativos no serviço? Qual(is)? Eles são liberados para realizarem cursos em outras instituições durante o período de trabalho?

14) Você sabe dizer se os profissionais participam de treinamentos e capacitações oferecidos pelos órgãos públicos? (Ministério da Saúde, Universidades).

15) Quais ações de Educação Permanente foram realizadas nos últimos anos? 
16) Como são acompanhadas e avaliadas as ações de Educação Permanente em Saúde?

17) Estamos passando por um período de grande troca de Recursos Humanos no município, existe algum planejamento para orientar esses novos trabalhadores dentro dos princípios e diretrizes no SUS?

Bloco 2: Financiamento e Recursos:

1) O município recebe algum recurso financeiro estadual e ou federal para implementação das ações de Educação Permanente em Saúde no município?

2) Qual a dotação orçamentaria que o município investe na politica de Educação Permanente em Saúde? 
APÊNDICE D- Roteiro para o Grupo Focal, direcionado aos coordenadores de distrito, responsáveis pelas equipes de Estratégia Saúde da Família

1) Conhecimento sobre a Política Nacional de Educação Permanente em Saúde (PNEPS) e sua articulação com a política municipal.

2) Explorar o grau de participação na elaboração da Educação Permanente em Saúde no município.

3) Buscar perceber se o grupo entende ser pertinente considerar a realidade, a necessidade e as expectativas locais e da equipe na formulação da Educação Permanente em Saúde no município. Em caso afirmativo, pedir que relatem como isso seria possível e como seria a contribuição deles. Em caso negativo, saber se acreditam serem efetivas medidas centralizadas e uniformes.

4) Instigá-los a pensar em temas que julgam importante abordar na Educação Permanente em Saúde com as equipes dos seus distritos e os motivos.

5) Saber se já participaram de algum curso de Educação Permanente oferecido pelo ministério (UnaSUS, Fiocruz, entre outros). Em caso afirmativo (é o que se espera, afinal, foi um critério para a seleção da amostra), qual foi o estímulo para fazer o curso e como o curso se traduz em sua prática profissional. Saber se alguém gostaria de ter feito algum outro curso e justificativa. 

APÊNDICE E- Questionário estruturado, direcionado aos profissionais atuantes na Estratégia Saúde da Família e no Núcleo de Apoio à Saúde da Família

1) O que você entende por Educação Permanente em Saúde?

2) Você já foi questionado sobre a necessidade e o interesse em Educação Permanente em Saúde no município? Considera que isso seria importante? Justifique.

3) Você acredita que são consideradas a realidade, a necessidade e as expectativas locais e da equipe na formulação da Educação Permanente em Saúde no município? Em caso afirmativo, você pode nos relatar como tem sido esse processo e a sua contribuição?

4) Quais os temas você acha importantes para serem abordados na Educação Permanente em Saúde para sua equipe? Justifique.

5) Qual a viabilidade para a realização de atividades de Educação Permanente no município? O que facilita e o que dificulta eventuais participações nestas atividades?

6) Você já participou de algum curso de Educação Permanente oferecido pelo ministério (UnaSUS, Fiocruz, entre outros)? Em caso afirmativo, (é o que se espera, afinal, foi um critério para a seleção da amostra), o que te estimulou a fazer o curso e como o curso se traduz na sua prática profissional? Gostaria de ter tido a oportunidade de fazer algum outro curso? Justifique.

7) Gostaria de fazer alguma outra manifestação a respeito da Educação Permanente? 

APENDICE F- Projeto de intervenção

Oficinas pedagógicas: $O$ processo de construção coletiva de uma proposta de Educação Permanente em Saúde

Produto Educacional gerado a partir da dissertação "A experiência da Educação Permanente em Saúde no município de Registro, São Paulo". Programa de Pósgraduação Mestrado Profissional Formação Interdisciplinar em Saúde. Faculdade de Odontologia, Faculdade de Saúde Pública, Escola de Enfermagem. Universidade de São Paulo.

Pós-graduanda: Daiane Mayara Alves Orientadora: Simone Rennó Junqueira

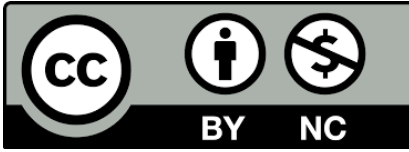

São Paulo 2019 
Oficinas pedagógicas: 0 processo de construção coletiva de uma proposta de Educação Permanente em Saúde

\section{Resumo}

Com a criação do SUS, e os novos perfis epidemiológicos, foi necessário ocorrer uma reformulação no processo de trabalho e uma constante atualização dos profissionais da saúde, e a Educação Permanente em Saúde (EPS) se coloca como uma importante ferramenta uma vez que as ações são realizadas dentro da realidade de cada equipe. Nesse pressuposto, esse produto educacional propõe a realização de oficinas que trabalhem a Política Nacional de Educação Permanente em Saúde (EPS), bem como as demais regulamentações vigentes da EPS com os enfermeiros das 19 unidades de ESF existentes no município de Registro- SP, com o intuito de formar facilitadores para ações futuras de EPS nas unidades de saúde, e ainda fortalecer a prática nas unidades de saúde.

Palavras-chave: Educação em Saúde. Estratégia Saúde da Família. Saúde Pública

\section{Justificativa}

Essa proposta didática é o produto educacional da dissertação intitulada: "A experiência da Educação Permanente em Saúde no município de Registro, São Paulo", pertencente ao Mestrado Profissional Formação Interdisciplinar em Saúde. Essa etapa contempla a aplicação do conhecimento adquirido no estudo e tem o objetivo de contribuir com o avanço da proposta da Educação Permanente em Saúde (EPS) no município através do uso de Oficinas Pedagógicas ${ }^{1}$.

Assim, partindo-se do pressuposto de que um dos principais nós críticos percebido no município foi o pouco conhecimento sobre a proposta da EPS entre alguns profissionais envolvidos no estudo, sejam eles médicos, cirurgiões-dentistas e enfermeiros da Estratégia Saúde da Família (ESF) ou trabalhadores de outras categorias profissionais do Núcleo de Apoio à Saúde da Família (NASF), sugere-se que o tema da Política Nacional de Educação Permanente em Saúde (PNEPS) seja difundido entre esses profissionais. O responsável pela EPS e coordenadores de distrito estavam mais apropriados da proposta ${ }^{1}$.

Nesse sentido, propõem-se uma dinâmica feita com os enfermeiros das ESF com o intuito de capacitá-los como facilitadores de EPS nas unidades de saúde. 
A Educação Permanente em Saúde trabalha com ferramentas que buscam a aprendizagem significativa e a reflexão critica sobre a prática cotidiana dos trabalhadores da saúde e busca uma formação integral e contínua e possibilita mudanças no processo de trabalho ${ }^{2,3}$. A escolha de trabalhar as oficinas com os enfermeiros justifica-se uma vez que esses além das atividades assistenciais prestadas aos pacientes, eles também exercem a função de gerentes das unidades de saúde, considerando que se forem capacitados podem reproduzir o conhecimento adquirido nas oficinas para os demais colaboradores das unidades de saúde.

\section{Desenvolvimento das Oficinas Pedagógicas}

Público-alvo: enfermeiros, responsáveis técnicos pelas Unidades Básicas de Saúde do município (estimativa de 19 profissionais).

Período de realização: são previstos três encontros presenciais, a serem realizados durante as reuniões de profissionais, que ocorrem mensalmente na Secretaria Municipal de Saúde.

10. Encontro:

Previamente ao primeiro encontro presencial deve ser encaminhado ao participante um e-mail contendo a Portaria GM/MS n 1.996 de 2007, que dispõe sobre as diretrizes para a implementação da Política Nacional de Educação Permanente em Saúde ${ }^{2}$, e o texto da Política Nacional de Educação Permanente em Saúde ${ }^{3}$. Esse será convidado a realizar uma leitura prévia do documento, fazendo anotações que julgar pertinente para serem debatidas ou esclarecidas no momento do encontro.

Sugere-se ainda a seguinte pergunta disparadora: "Quais os temas você acha importante para serem abordados na Educação Permanente em Saúde para sua equipe? Justifique". Dessa forma, espera-se que o participante faça um levantamento das sugestões de temas ou problemas percebidos por sua equipe e traga essa enquete para o primeiro encontro presencial. Importante enfatizar que não é necessária a identificação dos profissionais, nem mesmo da Unidade de Saúde.

A Política Nacional de Educação Permanente em Saúde traz em seu texto que as ações de EPS devem ser elaboradas de acordo com as necessidades locais, 
assim, serão levadas em consideração as necessidades de cada equipe para montar uma proposta coletiva na data do primeiro encontro ${ }^{3}$.

A Educação Permanente destaca a importância de espaços coletivos, nos quais diversos atores trabalham em conjunto na identificação de problemas e de ações para seu enfrentamento.

No primeiro encontro presencial, pretende-se trabalhar com a equipe de enfermeiros, criando um espaço para reflexão conjunta e troca de experiências através da metodologia pedagógica de roda, com o uso de técnicas que favoreçam o diálogo e a problematização. A ideia é demonstrar, na prática, a utilização da EPS, que pode ser realizada também nos momentos de reuniões semanais das equipes, consideradas um importante recurso para a organização do processo de trabalho.

Ao se pensar nas estratégias didáticas a serem utilizadas no ensino de profissionais da saúde, é preciso estimular métodos que facilitem a autonomia e o trabalho em grupo e que possibilitem a articulação entre teoria e prática. Dentre as possíveis estratégias destacam-se a metodologia de roda, o planejamento estratégico situacional, a metodologia da problematização com o método do Arco de Maguerez, seminários, oficinas e exposições dialogadas interativas ${ }^{4}$.

Considera-se que a metodologia de roda representa espaço coletivo de construção, estimula os participantes a interagir, expressar suas opiniões e experiências, discutir casos, aprender a escutar, interpretar e processar novos conhecimentos e trocar soluções.

A discussão dos problemas e nós críticos podem levar a melhorias na organização do processo de trabalho das equipes, muitas vezes com consequências positivas para além do caso inicial.

$1^{\circ}$. momento

Com o intuito de criar um espaço de compartilhamento de saberes, todos os participantes serão convidados a se sentar em roda e, após dinâmica de apresentação, como ponto inicial, será trabalhado o texto da Política Nacional de Educação Permanente em Saúde e da Portaria GM/MS n 1.996², o qual os participantes foram previamente convidados a realizar a leitura. Nesse momento, os participantes serão estimulados a exporem suas percepções a respeito dos textos e construir coletivamente o conceito de EPS. Deve ser reservado um tempo de trinta minutos para essa atividade, tempo esse que os participantes devem conhecer. 
Em seguida apresenta-se ao grupo o objetivo das Oficinas Pedagógicas e a proposta para os encontros. Será sugerida a metodologia da problematização, com o uso do Arco de Maguerez. Esse arco tem a realidade como ponto de partida e como ponto de chegada, como é possível observar na Figura $1^{5,6}$.

Figura 1: Esquema representativo da proposta de Maguerez.

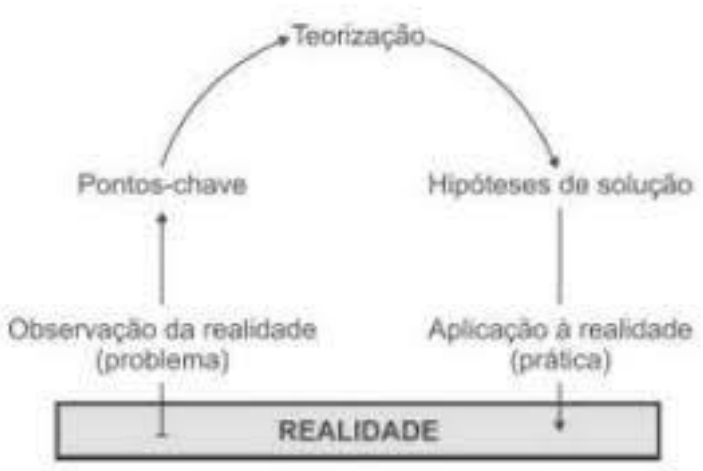

Fonte: apud Bordenave JD, Pereira AM. A7

Tem-se como referência o texto apresentado por Berbel (1995) para a área da educação, adaptando-a para a Educação em Saúde. A metodologia segue cinco passos essenciais: observação da realidade, definição de pontos chaves, teorização, análise, aplicação à realidade ${ }^{5}$.

Um dos intuitos das Oficinas Pedagógicas é de que esse método possa ser aplicado nas reuniões de equipes, como estratégia de EPS, assim, ensina-se e se aprende observando a realidade a partir de diversos ângulos e intervindo onde e quando os problemas acontecem, sendo aprendida não apenas teoricamente, mas vivenciada.

Como previamente os enfermeiros foram demandados sobre possíveis temas para atividades de Educação Permanente em suas equipes, a primeira fase do método da problematização será construída nesse primeiro encontro presencial.

As segunda, terceira e quarta etapa serão desenvolvidas no segundo encontro e a discussão da quinta etapa será realizada no terceiro encontro presencial.

$2^{\circ}$. momento

A primeira etapa do Método do Arco é a da observação da realidade e definição de um problema ${ }^{5,6}$. Essa etapa se iniciou na unidade de saúde, com o enfermeiro 
realizando um levantamento, com sua equipe, das sugestões de temas ou problemas percebidos para serem trabalhados na forma de Educação em Saúde.

No encontro presencial todos os enfermeiros participantes entregarão suas demandas levantadas em sua unidade. Caso todos estejam presentes e tenham realizado o levantamento, tem-se um número de 19 contribuições; essas serão entregues ao mediador no início da dinâmica.

Para reunir o conjunto de opiniões apresentadas pelos enfermeiros, e chegar a um consenso na proposta a ser trabalhada, será empregado o método Delphi normativo, que será adaptado às condições e tempo disponibilizado ${ }^{8}$.

O método Delphi normativo é focado na identificação e no estabelecimento de objetivos e prioridades, de modo a se estabelecer uma espécie de diálogo entre os participantes e, gradualmente, ir construindo uma resposta do grupo ${ }^{8}$.

As respostas serão analisadas pelo mediador e colaboradores presentes, como por exemplo, coordenadores de distrito e o responsável pela EPS, e serão observadas as tendências e as opiniões dissonantes, bem como suas justificativas, sistematizando-as e compilando-as em um painel para reapresentar ao grupo, estimulando uma discussão entre os participantes ${ }^{8}$.

Depois de o grupo conhecer as opiniões dos outros, cada participante tem a oportunidade de refinar, alterar ou defender suas respostas e apresentar novamente ao mediador para ser apresentado ao grupo, em uma nova rodada ${ }^{8}$.

Com exceção do primeiro painel, que será construído de forma anônima, tal como a metodologia preconiza, as demais rodadas serão construídas a partir do coletivo. Esse processo deve ser repetido até se atingir o maior número possível de respostas e opiniões de qualidade, de modo a subsidiar tomadas de decisão através de um consenso ${ }^{8}$. Para se evitar que o tempo se prolongue na definição dos problemas prioritários, pode-se fixar o tempo estabelecendo-se o máximo de quatro rodadas $^{8}$.

Portanto, se a primeira rodada considera os temas expressos livremente pelos enfermeiros, em função das opiniões dos membros de suas equipes, a segunda rodada será estruturada a partir da análise das respostas da primeira rodada, para a qual será montado um painel para apresentar ao grupo a lista de itens referidos pelos participantes, de maneira agrupada ${ }^{8}$. Será pedido a eles que os classifiquem ou ordenem, segundo critérios de relevância claros, de um a cinco ${ }^{8}$. Na terceira rodada, será elaborado um novo painel com base no grau de consenso; nessa etapa o grupo 
terá a oportunidade de alterar suas respostas, justificar as suas escolhas, e montar uma resposta de acordo com os consensos existentes no grupo ${ }^{8}$. Na quarta e última rodada, será definido um tema a ser trabalhado na metodologia da problematização da realidade, confrontando essas informações com os seus saberes experienciais ${ }^{8}$.

No final do processo será realizado um relatório final com o grupo e, desse momento, saíra a proposta concreta para ser trabalhada nas demais Oficinas Pedagógicas. Os participantes podem ser estimulados a buscarem material de referência sobre o tema para o próximo encontro.

Esse processo de definição de problema prioritário a ser trabalho por meio da Educação Permanente em Saúde deve ser conduzido posteriormente na própria Unidade de Saúde de origem de cada enfermeiro.

$2^{\circ}$. Encontro:

Definido o problema a ser estudado, em comum acordo entre os participantes, seguem-se as próximas fases da metodologia da problematização, a partir do Arco de Maguerez ${ }^{5,6}$. Nesse segundo encontro presencial, serão desenvolvidas as segunda, terceira e quarta etapa.

$2^{\circ}$ Etapa: definição de pontos chaves. Os participantes serão convidados a refletir, de modo crítico, sobre as possíveis causas e determinantes do problema eleito, iniciando por uma reflexão a respeito e identificando alguns possíveis fatores associados a ele, com o objetivo de melhor compreendê-lo $0^{5,6}$.

$3^{\circ}$ etapa: teorização. Compreende a imersão dos participantes no problema real percebido, nas observações diretas da realidade em foco, buscando atingir 0 conhecimento necessário para propor soluções, na etapa seguinte. Na perspectiva dos pontos chaves elencados, deve-se estudar o tema, investigando a possível origem, relação e interferência de cada um dos pontos chaves, buscando informações e analisando-as para melhor responder ao problema ${ }^{5,6}$. É momento de construir respostas mais elaboradas para essa etapa e pode-se lançar mão de todo material, dados e conhecimentos disponíveis ${ }^{5,6}$. É importante que os participantes sejam lembrados, com antecedência, sobre a possibilidade de trazerem material de referência e que a sala onde ocorra a Oficina tenha acesso à internet, para novas buscas bibliográficas ${ }^{5,6}$.

É importante destacar que, quando nos aproximamos dessa realidade, já possuímos alguns saberes, que englobam conhecimentos, crenças, competências, 
habilidades, que são incorporados e adquiridos de fontes diversas e que também devem ser considerados ${ }^{5,6}$.

$4^{\circ}$ etapa: hipóteses de solução. Todo conteúdo produzido até essa etapa deve servir para a transformação da realidade. Com base nas reflexões realizadas nas etapas anteriores, elaboram-se as hipóteses de solução para o problema, tendo em vista o recorte da realidade. Essa é uma etapa em que a criatividade e originalidade devem ser estimuladas ${ }^{5,6}$.

Ao elaborar as hipóteses de solução, os participantes confrontam suas ideias, experiências, expectativas, conhecimentos teóricos prévios, suas propostas com os dados disponíveis, momento oportuno de transformar toda a teoria elaborada em prática ${ }^{5,6}$.

No final desse encontro o próprio mediador ou um relator, deverá escrever um relatório com a síntese do grupo.

Tendo em vista a experiência com a dinâmica, recomenda-se que os participantes retornem à suas Unidades de Saúde de origem e apliquem essas fases durante a reunião de equipe, dando sequência à discussão iniciada. Assim, para o terceiro e último encontro, espera-se que os enfermeiros tragam uma síntese do que foi discutido com sua equipe de saúde.

\section{Encontro:}

Finalizando toda a imersão, a quinta e última etapa pressupõe o uso das sínteses das experiências vivenciadas nos encontros com as equipes ${ }^{5,6}$.

Essa etapa é considerada a etapa da prática, da realização das hipóteses de solução mais viáveis e factíveis. Nessa etapa, os participantes analisam a aplicabilidade das hipóteses e realizam a aplicação de uma ou mais das hipóteses de solução, como um retorno do estudo à realidade investigada ${ }^{5,6}$.

Deve-se aqui verificar a governabilidade de execução, a real necessidade e a prioridade. O importante é garantir alguma forma de aplicação real das soluções geradas pelo grupo ${ }^{5,6}$.

Ao final dessa etapa também será realizado um relatório final que, agregado aos demais, conterá todo o percurso das Oficinas Pedagógicas.

Assim, espera-se que, em todas as Unidades de Saúde do município, a Educação Permanente em Saúde possa ser vivenciada e discutida. A partir do problema definido como prioritário, que o mesmo possa ser visto como uma 
oportunidade de aprendizado e que emerjam propostas para sua solução ou minimização. E essa possibilidade de interferência, vinda a partir de uma construção coletiva, é que se revela com potencial transformador em favor de uma prática de saúde pautada na cidadania.

A figura 2 exemplifica a proposta desta Oficina Pedagógica, aplicada a partir de um piloto realizado em uma Equipe de Saúde da Família do município.

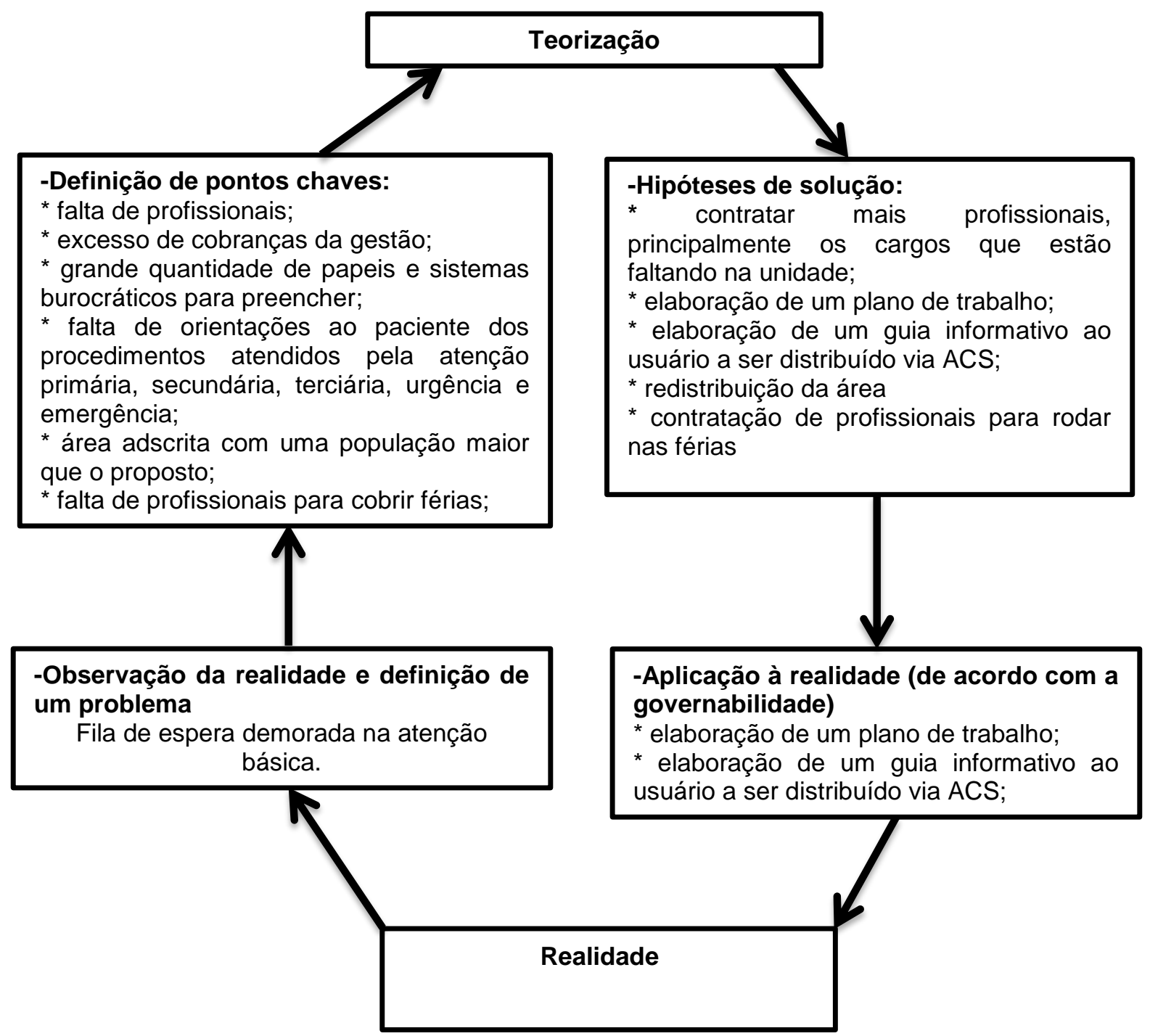

Fonte: Oficina Pedagógica em Unidade Estratégia Saúde da Família, elaborado pelo autor. 


\section{Referências:}

1. ALVES, DM; JUNQUEIRA, SR. A experiência da Educação Permanente em Saúde no município de Registro, São Paulo.

2. Brasil. Ministério da Saúde. Dispõe sobre as diretrizes para a implementação da Política de Educação Permanente em Saúde. Portaria n 1.996/GM, 20 agosto 2007.

3. Ministério da Saúde. Secretaria de Gestão do Trabalho e da Educação na Saúde. Departamento de Gestão da Educação na Saúde. Política Nacional de Educação Permanente em Saúde: Brasília: Ministério da Saúde; 2009. 65p.

4. Santos JLG, Souza CSBN, Tourinho FSV, Sebold LF, Kempfer SS, Linch GFC. Estratégias didáticas no processo de ensino-aprendizagem de gestão em enfermagem. Texto Contexto Enferm, 2018; 27(2).

5. Barbel NAN. Metodologia da Problematização: Uma alternativa Metodológica apropriada para o Ensino Superior. Semina: Ciências Sociais e Humanas; 1995; 16(2): 9-19.

6. Colombo AA, Berbel NAN. A Metodologia da Problematização com o Arco de Maguerez e sua relação com os saberes de professores. Semina: Ciências Sociais e Humanas, 2007; 28 (2): $121-46$.

7. Bordenave JD, Pereira AM. Estratégias de ensino aprendizagem. $4^{\circ}$ Ed. Petropolis: Vozes, 1989.

8. Marques JBV, Freitas D. Método DELPHI: caracterização e potencialidades na pesquisa em Educação. Pro. Posições, 2018; 29(2): 389-415. 
ANEXO A- Parecer do Comitê de Ética em Pesquisa

USP - FACULDADE DE
ODONTOLOGIA DA
UNIVERSIDADE DE SÃO

\section{PARECER CONSUBSTANCIADO DO CEP}

\section{DADOS DO PROJETO DE PESQUISA}

Título da Pesquisa: A experiência da Educaçăo Permanente em Saúde no municipio de Registro, São Paulo: estudo de caso

Pesquisador: DAIANE MAYARA ALVES

Área Temática:

Versăo: 1

CAAE: 89008318.4 .0000 .0075

Instituiçăo Proponente: Faculdade de Odontologia da Universidade de Săo Paulo

Patrocinador Principal: Financiamento Próprio

\section{DADOS DO PARECER}

Número do Parecer: 2.701 .759

\section{Apresentaçáo do Projeto:}

Estudo de campo de base qualitativa, compreendendo um levantamento documental do material relacionado à educação permanerte em saúde no municipio, complementado por

entrevista individual a partir de questionário estruturado, com o responsável pela educação permanente em saúde. Coordenadores dos trés distritos de saúde participarão do Grupo Focal expondo suas percepçóes scobre o tema. Posteriomente, se buscará conhecer as percepçōes de profissionais atuantes na Estratégia Saúde da Familia e no Núcleo de Apoio à Saúde da Familia, em entrevistas individuais conduzidas por questionário semi-estruturado. Participantes: profissionais com mais de trés anos de atuaçăo nas respectivas equipes, independentemente da categoria profissional, mas que tenham participado de alguma atividade de educação permanente oferecida em parceria pelo Ministério da Saúde. O Grupo Focal e todas as entrevistas serâo gravadas, com a finalidade de facilitar a transcrição para a análise. A útima etapa de análise de todo o conteúdo escrito, irá articular essas informaçóes com conhecimentos lebricos e legislafvos scobre a temática, visando a proposiçăo de açóes de educaçăo permanente em saúde.

\section{Objetivo da Pesquisa:}

O objetivo geral deste projeto é o de apresentar o processo de planejamento e organizaçăo das açóes de educaçăo permanente em saúde desenvoivido no municipio de Registro, SP. O objetivo secundário devrá descrever e analisar o processo de elaboraçăo das açóes de educaçăo

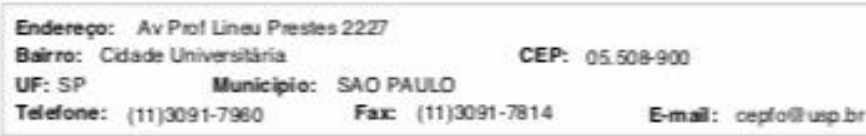




\section{USP - FACULDADE DE ODONTOLOGIA DA UNIVERSIDADE DE SÃO}

Conthuagso do Panocer: 2701.759

permanente em saúde no municipio, correlacionando-o com as legislaçóes pertinentes em vigor no periodo do estudo; apresentar propostas que possam colaborar para o incremento das açóes que compóem o plano municipal de educaçăo permanente.

Avaliaçăo dos Riscos e Benefícios:

A possibilidade de risco ao participante é minima, podendo ocorrer pontualmente uma perturbaçäo nas atividades de trabalho, a exposiçăo de ideias ou ao constrangimento, porém o sigilo e anonimato serắo garantidos, mesmo após a finalização e publicação dos resultados.

Beneficios: os participantes năo terăo nenhum beneficio direto, bem como não receberăo nenhum pagamento, mas a sua contribuiçăo poderá acrescentar elementos importantes à literatura.

\section{Comentários e Consideraçobes sobre a Pesquisa:}

Pesquisa bem delineada e explicitada, devendo substanciar propostas que possam colaborar para o incremento das açóes que compóem o plano municipal de educaçâo permanente.

\section{Consideraçóes sobre os Termos de apresentaçăo obrigatória:}

Apresenta TCLE, Termo de Autorizaçăo da Secretaria da Saúde - Registro - Săo Paulo e demais termos obrigatónios.

\section{Recomendaçöes:}

Tendo em vista a legislaçăo vigente, devem ser encaminhados ao CEP.FOUSP relatorios parciais anuais relerentes ao andamento da pesquisa e relatório final, utilizando-se da opçăo "Enviar Notificaçăo" (descrita no Manual "Submeter Notificaçăo", disponivel na Central de Suporte - canto superior direito do site www.saude.gov.br/plataformabrasil).

Qualquer alteração no projeto original deve ser apresentada "emenda" a este CEP, de forma objetiva e com justificativas para nova apreciação.

Conclusobes ou Pendências e Lista de Inadequaçóes:

Năo săo observadas inadequaçōes e pendências.

Consideraçóes Finais a critério do CEP:

Este parecer foi elaborado baseado nos documentos abaixo relacionados:

\begin{tabular}{|c|c|c|c|c|}
\hline Tipo Documento & Arquivo & Postagem & Autor & Situaçăo \\
\hline $\begin{array}{l}\text { hlormaçóes Básicas } \\
\text { do Projeto }\end{array}$ & $\begin{array}{l}\text { PB_INFORMACCOES_BASICAS_DO_P } \\
\text { RONETO } 1122377 . \mathrm{pdt}\end{array}$ & $\begin{array}{c}03 / 05 / 2018 \\
09 \cdot 30,40\end{array}$ & & Aceito \\
\hline Folha de Rosto & FolhadeRos b.pdf & $\begin{array}{c}03 / 05 / 2018 \\
09-26-01\end{array}$ & $\begin{array}{l}\text { DAIANE MAYARA } \\
\text { ALYES }\end{array}$ & Aceito \\
\hline
\end{tabular}

Endereç: Av Prot Lineu Prestes 2220

Bair ro: Cdade Universitária

CEP. 05.508900

UF: SP Municipio: SAO PAULO

Telefone: (11)3091-7960 Fax (11)3091-7814 E-mal: ceploluep br 